\title{
Preparation and Application of Garnet Electrolyte Thin Films: Promise and Challenges
}

\author{
Xufeng Yan, Weiqiang Han* \\ Department of Materials Science and Engineering, Zhejiang University, Hangzhou 310027, China \\ Email: hanwq@zju.edu.cn
}

\begin{abstract}
All-solid-state batteries (ASSBs) have attracted much attention in recent years, due to their high energy density, excellent cycling performance, and superior safety property. As the key factor of all-solid-state batteries, solid electrolyte determines the performance of the batteries. Garnet-typed cubic- $\mathrm{Li}_{7} \mathrm{La}_{3} \mathrm{Zr}_{2} \mathrm{O}_{12}(\mathrm{LLZO})$ has been reported as the most promising solid electrolyte on the way to ASSBs. Thin film electrolyte could contribute to a higher energy density and a lower resistance in a battery. This short review exhibits the latest efforts on LLZO thin film and discusses the different preparation methods, together with their effects on characteristics and electrochemical performances of the solid electrolyte film.
\end{abstract}

Keywords: lithium batteries, all solid-state batteries, solid electrolytes, garnets, LLZO

\section{Introduction}

After being commercialized by Sony in 1991, Lithium-ion batteries (LIBs) have gradually become one of the popular energy storage devices, and have widespread applications in electronic devices, electric vehicles and smart grid systems. ${ }^{[1-3]}$ However, the conventional LIBs based on flammable organic liquid electrolytes, faced the inherent safety issues of leakage, fire, and explosion, especially in the development of large-scale LIBs ${ }^{[4,5]}$.

Compared with the traditional lithium ion batteries, all-solid-state batteries (ASSBs) have attracted much attention in recent years, duo to the high energy density, excellent cycling performance and serious safety. The replacement of flammable organic liquid electrolytes by inorganic materials in ASSB limited the safety issues. ${ }^{[6]}$ In addition, different from the liquid electrolytes, the solid electrolytes have a wider stable electrochemical window and the inhibition of lithium dendrite penetration. Lithium metal anode and high voltage cathode are befitting electrode materials in ASSB, which result in a higher energy density of lithium battery ${ }^{[7-10]}$.

Solid electrolyte is the key factor of all-solid-state batteries, which determines the performance of the batteries. Among the reported solid electrolytes, sulfide-based electrolytes show the highest ionic conductivity. According to the reports, the value of sulfide-based electrolytes ionic conductivity was as high as $10^{-2} \mathrm{~S} \mathrm{~cm}^{-1}$, some results even to $10^{-1} \mathrm{~S} \mathrm{~cm}^{-}$ ', the values were comparable to or higher than traditional liquid electrolytes ${ }^{[11,12]}$. However, the sulfide-based electrolytes are not stable in the air condition. On the contrary, the oxide solid electrolytes showed more stabilities than sulfide-based electrolytes ${ }^{[2]}$. In the numerous oxide solid electrolyte, garnet-typed cubic $\mathrm{Li}_{7} \mathrm{La}_{3} \mathrm{Zr}_{2} \mathrm{O}_{12}$ (LLZO) has a relatively higher ionic conductivity, wider electrochemical window and more excellent stability against lithium metal. It is reported as the most promising solid electrolyte among the oxide solid electrolyte ${ }^{[1,10,13]}$.

However, the development of solid electrolyte is restricted by some challenges, such as its low ionic conductivity and large interfacial resistance. Lots of works focused on these issues have been reported to improve the above restrictions, such as the improvement of ionic conductivity by elements doping ${ }^{[14-16]}$, the enhancement of density of LLZO pellet by improving the sintering technology ${ }^{[17-19]}$, the alleviation of interface issues by changing the contact ${ }^{[20-22]}$ or adding a buffer layer ${ }^{[23,24]}$.

Elements doping is a significant way to improve ionic conductivity. According to the difference of dopant site, there are three doping sites in the material of LLZO ${ }^{[25]}$. In mass of element doping works, $\mathrm{Al}^{3+} / \mathrm{Ga}^{3+}$ doped ${ }^{[26-28]}$ on Li site, $\mathrm{W}^{6+} /$ $\mathrm{Ta}^{5+} / \mathrm{Y}^{3+}$ resided $\mathrm{Zr}$ site ${ }^{[29-32]}$ and some multiple element doping showed obvious efforts. For example, $\mathrm{Li}_{6.4} \mathrm{La}_{3} \mathrm{Zr}_{1.4} \mathrm{Ta}_{0.6} \mathrm{O}_{12}{ }^{[33]}$ and $\mathrm{Li}_{6.20} \mathrm{Ga}_{0.3} \mathrm{La}_{2.95} \mathrm{Rb}_{0.05} \mathrm{Zr}_{2} \mathrm{O}_{12}{ }^{[14]}$ showed the highest ionic conductivity, over $10^{-3} \mathrm{~S} \mathrm{~cm}^{-1}$ at room temperature. 
Another method to increase the ionic conductivity value is increasing the density of LLZO pellet, which involving the solid state sintering technology ${ }^{[34]}$. Rangasamy et al. ${ }^{[35]}$ used the hot press technique to sinter LLZO pellet. The $\mathrm{Li}_{6.24} \mathrm{La}_{3} \mathrm{Zr}_{2} \mathrm{Al}_{0.24} \mathrm{O}_{11.98}$ pellet was heated at $1000{ }^{\circ} \mathrm{C}$ under $40 \mathrm{MPa}$ pressure for $1 \mathrm{~h}$ and showed an ionic conductivity of $4 \times 10^{-4} \mathrm{~S} \mathrm{~cm}^{-1}$ with a relative density of $98 \%$. Later, the hot isostatic pressing was introduced in sintering LLZO. With this method, the density of the Al-doped LLZO pellet was increased from $91.5 \%$ to $99.1 \%$, which contributed a high ionic conductivity of $9.9 \times 10^{-4} \mathrm{~S} \mathrm{~cm}^{-1}$ at $25{ }^{\circ} \mathrm{C}^{[19]}$. Moreover, fast microwave-assisted sintering ${ }^{[36]}$ and spark plasma sintering ${ }^{[37]}$ were discovered in the preparation of LLZO bulk materials. The Ta-doped LLZO pellet, obtained by spark plasma sintering technique, showed the ionic conductivity of $1.35 \times 10^{-3} \mathrm{~S} \mathrm{~cm}^{-1}$ at $25^{\circ} \mathrm{C}$ and $1.23 \times 10^{-2} \mathrm{~S} \mathrm{~cm}^{-1}$ at $80^{\circ} \mathrm{C}^{[37]}$. In addition, many fillers materials, such as $\mathrm{Li}_{2} \mathrm{O}^{[38]}, \mathrm{Li}_{3} \mathrm{PO}_{4}{ }^{[39]}, \mathrm{Li}_{4} \mathrm{SiO}_{4}{ }^{[40]}, \mathrm{LiBO}_{3}{ }^{[41]}, \mathrm{LiF}^{[42]}$, were added into the LLZO powder during the sintering process, which method decreased the grain-boundary resistance successfully.

Interface issues, the key factor of ASSBs, limited the applications of solid state electrolyte ${ }^{[43]}$. The causes of interface issues in ASSBs could be divided into different parts. First, compared with the liquid-solid contact in conventional lithium battery, ASSBs had less active sites due to the solid-solid contact between electrode and electrolyte ${ }^{[44-46]}$. Second, the space charge layer caused by the potential difference was existing in the interface ${ }^{[47-49]}$. Third, the volume expansion of electrode materials made the contact worse and worse during the charging-discharging cycles ${ }^{[50]}$. Last, the elements diffusion rested in the interface by reason of the concentration difference ${ }^{[51]}$. Kim et al. ${ }^{[52]}$ investigated the interfacial issue of $\mathrm{LiCoO}_{2} /$ LLZO/Li by the TEM characterization of the interface. The result showed the formation of an intermediate caused by the vary elements diffusion, which contributed to the high interfacial resistance and poor lithium insertion-extraction behavior. Kato et al. ${ }^{[53]}$ modified the interface by the deposition of a thin $\mathrm{Nb}$ layer. A low resistivity-amorphous layer of Li-Nb-O formed in the interface, which avoided the influences of elements diffusion and made a lower space charge layer. Luo et al. ${ }^{[54]}$ improved the contact issue between LLZO and lithium metal by coating an ultrathin amorphous Si layer. During the cycling, the layer transformed to a super-lithiophilicity, which contributed to a lower interface resistance.

Owning to the progresses above, preliminary results of the LLZO applications in ASSB have been achieved. Ohta et al. ${ }^{[5]}$ reported an application of Nb-doped LLZO pellet in the Li/LLZONb/LCO solid state battery. In the work, the excellent cycling performance of the cell was attributed to a well contact interface. They deposited cathode LCO on the LLZONb pellet by the method of pulsed laser deposition (PLD), which contributed to the well contact between the solid electrolyte layer and the cathode layer. Later, for element doping and high relative density of Ta-doped LLZO, Guo et al. ${ }^{[33]}$ showed a high ionic conductivity of LLZTO pellet, as high as $1.6 \times 10^{-3} \mathrm{~S} \mathrm{~cm}^{-1}$, which was the key factor of the all-solidstate battery performance at high temperature. $\mathrm{Li}$ et al. ${ }^{[42]}$ introduced $\mathrm{LiF}$ to $\mathrm{Li}_{6.5} \mathrm{La}_{3} \mathrm{Zr}_{1.5} \mathrm{Ta}_{0.5} \mathrm{O}_{12}$ (LLZTO) to increase the stability and the electrolyte showed a small interfacial resistance with Li anode. The LLZTO pellet was applied both in the LFPO/Li and Li-S battery. Recently, Kun (Kelvin) Fu et al. ${ }^{[56]}$ prepared the garnet electrolyte of $\mathrm{Li}_{7} \mathrm{La}_{2.75} \mathrm{Ca}_{0.25} \mathrm{Zr}_{1.75} \mathrm{Nb}_{0.25} \mathrm{O}_{12}$ and modified the electrolyte/metallic Li interface with an ultrathin Al layer. By this method, a good Li wetting lied in the interface and got more stable performances in Li-ion, Li-sulfur, and Li-oxygen batteries.

After the first report of LLZO ${ }^{[57]}$, most of the researches were focused on the LLZO bulk ceramic electrolyte, only a few work have been made to the LLZO thin film. Compared to the bulk ceramic electrolyte, thin film has one advantage. The lithium diffusion time will be decreased a lot. The lithium diffusion time $t$ and the thickness of electrolyte layer $\mathrm{L}$ are proportional to the square, (D, diffusion constant). When $\mathrm{L}$ is reduced, it is more largely reduced ${ }^{[9]}$.

According to the previous reports, LLZO has been applied in thin film as solid electrolyte. This review will summarize the preparation methods, characteristics and electrochemical performances of LLZO thin film. Section 2 focused on different methods of deposition. The method and as-prepared thin film of sol-gel method covered in Section 3. Section 4 showed an LLZO film and its applications by focused ion beam milling. The last Section discussed the LLZO composite electrolyte thin film and the characteristics of ASSBs.

\section{Methods of deposition}

Deposition methods were the intuitionistic way of preparing thin films. This section discusses the five kinds of deposition method: Pulsed laser deposition (PLD), Radio-frequency (RF) magnetron sputtering, Chemical vapor deposition (CVD), Atomic layer deposition (ALD) and Aerosol deposition (AD) method.

\subsection{Pulsed laser deposition (PLD)}

Pulsed laser deposition (PLD) was firstly carried out as a method to prepare LLZO films in the year of $2012^{[99,60]}$. The prepared amorphous LLZO had a large optical band gap of $5.13 \mathrm{eV}$, and the value was reduced to $3.64 \mathrm{eV}$ after the treatment of annealing ${ }^{[59]}$. With a Laser-annealing treatment, the ionic conductivity was increased from $3.35 \times 10^{-7} \mathrm{~S} \mathrm{~cm}^{-1}$ 
to $7.36 \times 10^{-7} \mathrm{~S} \mathrm{~cm}^{-1}{ }^{[60]}$. Rawlence et al. ${ }^{[61]}$ prepared LLZO film on the MgO substrate by PLD technique (Fig. 1c), with a thickness of $380 \mathrm{~nm}$. The film showed an ionic conductivity of $1.2 \times 10^{-3} \mathrm{~S} \mathrm{~cm}^{-1}$ at $325^{\circ} \mathbf{C}$. Reinacher et al. ${ }^{[62]}$ reported that garnet-type $\mathrm{Li}_{6} \mathrm{BaLa}_{2} \mathrm{Ta}_{2} \mathrm{O}_{12}$ thin films were prepared on $\mathrm{MgO}$ (100) single crystals by the way of pulsed laser deposition.

The ionic conductivity of the film was $1.7 \times 10^{-6} \mathrm{~S} \mathrm{~cm}^{-1}$ at room temperature, which was a little lower than the bulk value

(a)

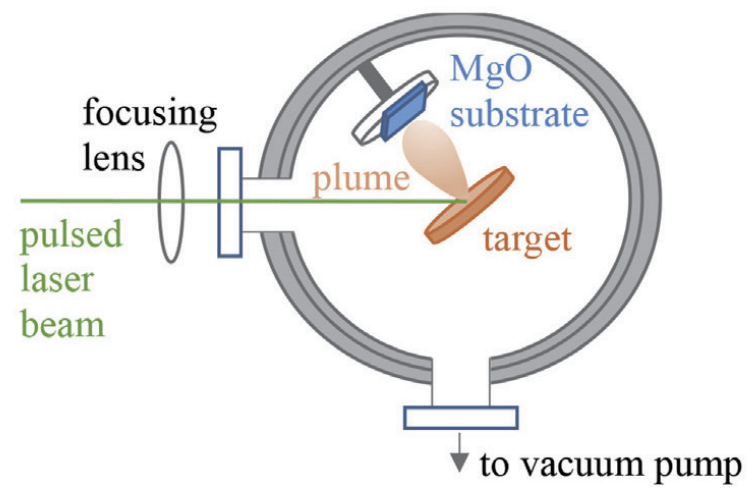

(b)

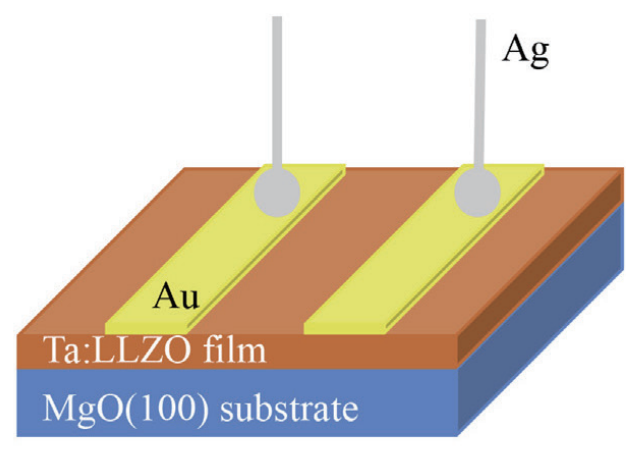

Figure 1. (a) Schematic of the deposition process (b) Experimental set-up for the conductivity measurements ${ }^{[58]}$

of $5.0 \times 10^{-6} \mathrm{~S} \mathrm{~cm}^{-1}$. PLD technique was also successfully used in deposition of epitaxial LLZO film ${ }^{[63]}$. On the $\mathrm{Gd}_{3} \mathrm{Ga}_{5} \mathrm{O}_{12}$ (GGG) substrate, LLZO (001) and LLZO (111) were obtained. At room temperature, the ionic conductivities in the grains of the (001) and (111) films were $2.5 \times 10^{-6} \mathrm{~S} \mathrm{~cm}^{-1}$ and $1.0 \times 10^{-5} \mathrm{~S} \mathrm{~cm}^{-1}$. On the basis work ${ }^{[64]}$ of preparing the LLZO film on AAO (Fig. 2d \& 2e), Park et al. ${ }^{[65]}$ studied the effects of substrate temperatures and impurities on electrochemical properties of the film, which was prepared by PLD method. In the work, the film was deposited both on Si and AAO substrate and the SEM of the section in figure 2a and figure $\mathbf{2 b}$. The result showed that the film was in a mixture of cubic and tetragonal phases of LLZO in the condition of deposition temperature above $600^{\circ} \mathbf{C}$. Figure $\mathbf{2 b}$ also revealed the upper region of the film was rich in aluminum and oxygen by an EDS scan along the dotted line. In the EDS analysis, the counts of aluminum element in this region was comparable to the AAO substrate.

The film, deposited at $600{ }^{\circ} \mathrm{C}$, exhibited the highest room temperature conductivity of $1.61 \times 10^{-6} \mathrm{~S} \mathrm{~cm}^{-1}$. Saccoccio et al. ${ }^{[58]}$ studied the low temperature PLD method in fabricating pure cubic LLZO film on MgO (100) substrates. According to the work, having a range deposition temperature from $50{ }^{\circ} \mathrm{C}$ to $700{ }^{\circ} \mathrm{C}$, the ionic conductivities of the films were not significantly influenced.

\subsection{Radio Frequency (RF) magnetron sputtering}

Radio-frequency (RF) magnetron sputtering is also a common technique for preparing films. Kalita et al. ${ }^{[69]}$ firstly deposited amorphous lithium-lanthanum-zirconium-oxide (Li-La-Zr-O) film by the method of RF magnetron sputtering. The thickness of films could be changed by varying the RF power. The thickness, which could be seen in Figure 3a3c, were $561 \mathrm{~nm}$ at $40 \mathrm{~W}, 861 \mathrm{~nm}$ at $60 \mathrm{~W}$ and $941 \mathrm{~nm}$ at $80 \mathrm{~W}$. The film deposited at $40 \mathrm{~W}$ showed the highest ionic conductivity of $4 \times 10^{-7} \mathrm{~S} \mathrm{~cm}^{-1}$, compared with the $60 \mathrm{~W}$ and $80 \mathrm{~W}$ samples which showed the ionic conductivity values of $2 \times 10^{-7} \mathrm{~S} \mathrm{~cm}^{-1}$ and $0.8 \times 10^{-7} \mathrm{~S} \mathrm{~cm}^{-1}$ respectively.

Compared with the amorphous lithium-lanthanum-zirconium-oxide (Li-La-Zr-O) film work ${ }^{[69]}$, Lobe et al. ${ }^{[70]}$ deposited Ta- and Al-substituted LLZO thin films on stainless steel substrates by radio-frequency (RF) magnetron sputtering at high temperature. According to the result of depositions at different temperatures, LLZO formation started at around $650{ }^{\circ} \mathrm{C}$ and single phase cubic thin films were obtained at $700{ }^{\circ} \mathrm{C}$. Figure 3d and Figure $3 \mathbf{e}$ showed the films at the deposition temperature of $700{ }^{\circ} \mathrm{C}$ and $800^{\circ} \mathrm{C}$. The film showed the ionic conductivity values of $1.2 \times 10^{-4} \mathrm{~S} \mathrm{~cm}^{-1}$ (in-plane, Fig $2 \mathrm{f}$ ) and $2.0 \times 10^{-9} \mathrm{~S} \mathrm{~cm}^{-1}$ (perpendicular to the plane).

\subsection{Chemical vapor deposition (CVD)}

This part mainly covers two components: metal organic chemical vapor deposition (MOCVD) and laser assisted chemical vapor deposition (LACVD).

As a technique for the preparation of thin films, MOCVD technique shows advantages on high deposition rates and moderate vacuum conditions. In addition, the morphology and phase formation can be controlled during the process of 
preparation of films by the MOCVD method. Equipped with the experience of the LCO film, Katsui et al. ${ }^{[71]}$ prepared cubic and tetragonal LLZO film on polycrystalline $\mathrm{Al} 2 \mathrm{O} 3$ by metal organic chemical vapor deposition with a high rates of $20 \mu \mathrm{m} \mathrm{h}^{-1}$. Additionally, they investigated the influence of deposition temperature (Tsub), a key factor in the process, on the
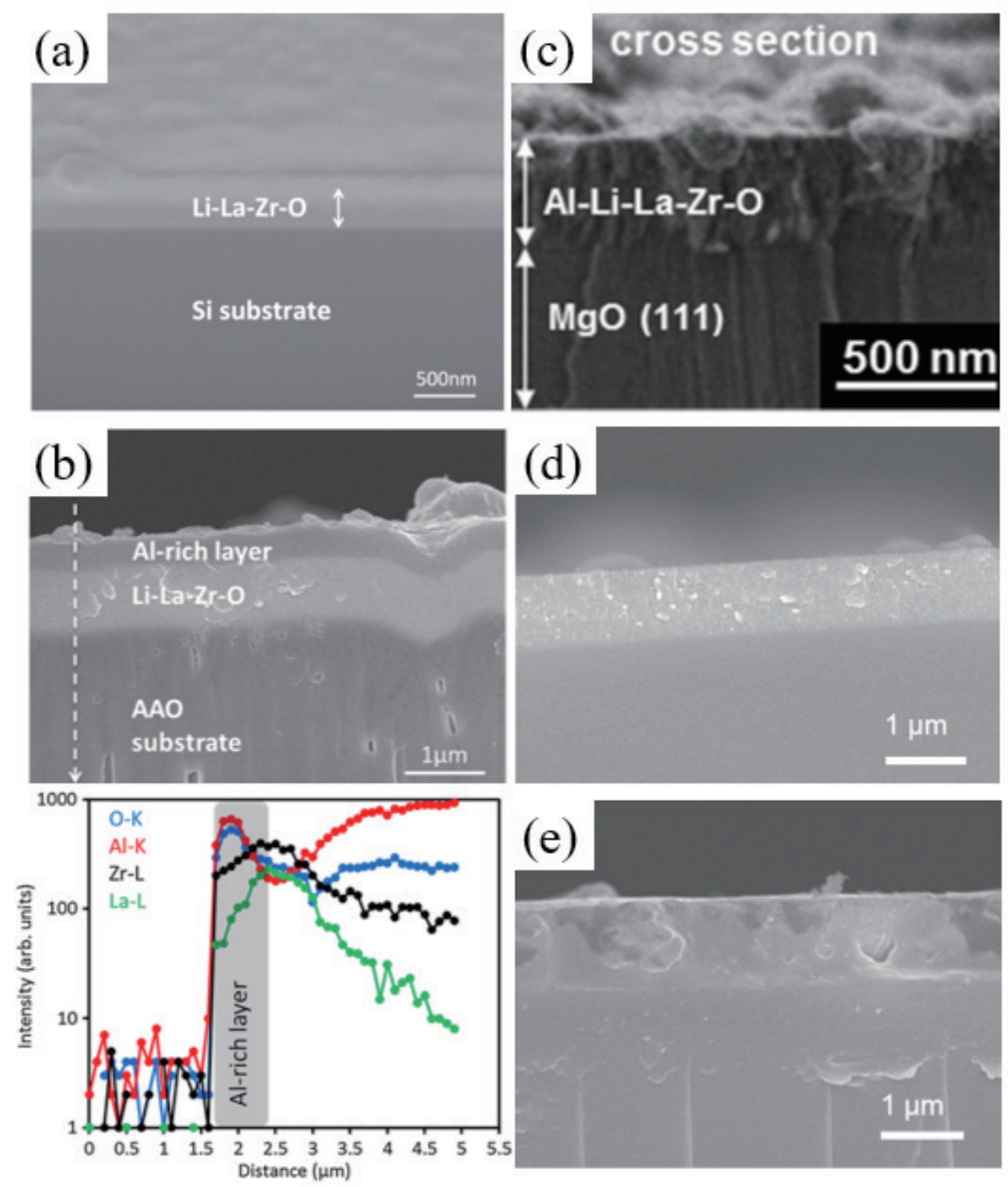

Figure 2. (a) SEM cross-section image of a $200 \mathrm{~nm}$ thick $\mathrm{Li}-\mathrm{La}-\mathrm{Zr}-\mathrm{O}$ film ${ }^{[65]}$;(b) SEM image of a polished cross section of the Li-La-Zr-O film deposited on an AAO substrate at $700{ }^{\circ} \mathrm{C}$ and the corresponding EDS profile along the indicated line ${ }^{[65]} ;$ (c) An as-deposited $\mathrm{Li}_{7} \mathrm{La}_{3} \mathrm{Zr}_{2} \mathrm{O}_{12}$ based thin film deposited on a single crystal MgO substrate at $50{ }^{\circ} \mathrm{C}$ by PLD, cross-sectional SEM micrograph ${ }^{[6]}$; (d)-(e) Cross sectional SEM of LLZO films ${ }^{[64]}$ : (d) sapphire substrate at room temperature; (e) sapphire substrate at $700^{\circ} \mathrm{C}$ 
Table 1. List of the garnet type films by the PLD technique with an outline of the material, year, substrate, thickness, room temperature ionic conductivity and activation energy

\begin{tabular}{|c|c|c|c|c|c|c|}
\hline Material & Year & Substrate & Thickness & $R T \sigma_{\mathrm{Li}}\left[\mathrm{S} \mathrm{cm}^{-1}\right]$ & $\mathbf{E}_{\mathrm{a}}[\mathrm{eV}]$ & Ref. \\
\hline $\mathrm{Li}_{6.4} \mathrm{La}_{3} \mathrm{Zr}_{1.4} \mathrm{Ta}_{0.6} \mathrm{O}_{12}$ & 2017 & MgO (100) & $\sim 40 \mathrm{~nm}$ & - & - & \multirow[b]{2}{*}{ [60] } \\
\hline \multirow[b]{2}{*}{$\mathrm{Li}_{7} \mathrm{La}_{3} \mathrm{Zr}_{2} \mathrm{O}_{12}$} & \multirow[b]{2}{*}{2012} & STO (100) & \multirow[b]{2}{*}{-} & $7.36 \times 10^{-7}$ & 0.32 & \\
\hline & & Sapphire (0001) & & $3.35 \times 10^{-7}$ & 0.36 & [59] \\
\hline $\mathrm{Al}-\mathrm{Li}_{7} \mathrm{La}_{3} \mathrm{Zr}_{2} \mathrm{O}_{12}$ & 2013 & $\mathrm{AAO}$ & $1000 \mathrm{~nm}$ & - & - & [66] \\
\hline $\mathrm{A} 1-\mathrm{Li}_{7} \mathrm{La}_{3} \mathrm{Zr}_{2} \mathrm{O}_{12}$ & 2016 & $\mathrm{MgO}(100)$ & $90-380 \mathrm{~nm}$ & $1.2 \times 10^{-3}$ & 1.39 & [67] \\
\hline $\mathrm{Li}_{6} \mathrm{BaLa}_{2} \mathrm{Ta}_{2} \mathrm{O}_{12}$ & 2014 & $\mathrm{MgO}(100)$ & $\sim 200 \mathrm{~nm}$ & $2 \times 10^{-6}$ & 0.42 & [62] \\
\hline \multirow{2}{*}{$\mathrm{Al}-\mathrm{Li}_{7} \mathrm{La}_{3} \mathrm{Zr}_{2} \mathrm{O}_{12}$} & \multirow{2}{*}{2013} & GGG (001) & $26.2 \mathrm{~nm}$ & $2.5 \times 10^{-6}$ & 0.55 & [68] \\
\hline & & GGG (111) & $30.4 \mathrm{~nm}$ & $1.0 \times 10^{-5}$ & 0.52 & \multirow{2}{*}[65]{} \\
\hline $\mathrm{Li}_{7} \mathrm{La}_{3} \mathrm{Zr}_{2} \mathrm{O}_{12}$ & 2015 & $\operatorname{MgO}(100)$ & $100-200 \mathrm{~nm}$ & $1.61 \times 10^{-6}$ & 0.35 & \\
\hline
\end{tabular}

formation of phase, morphology and deposition rates. When Tsub was $973 \mathrm{~K}$, a pyrochlore type $\mathrm{La}_{2} \mathrm{Zr}_{2} \mathrm{O}_{7}$ film having the (111) orientation was deposited. In the range from 1023 to $1173 \mathrm{~K}$ of Tsub, the phase of LLZO films was tetragonal. Cubic LLZO films with fine granular surface were obtained at Tsub $=1173-1223 \mathrm{~K}$. Figure $5 \mathrm{c}$ and $5 \mathrm{~d}$ showed the tetragonal LLZO film at $1073 \mathrm{~K}$ and the cubic LLZO film at $1223 \mathrm{~K}$.

Loho et al. ${ }^{[72]}$ prepared the tetragonal LLZO film on Pt layer by a novel $\mathrm{CO}_{2}$-laser assisted chemical vapor deposition (LACVD) technique. The total ionic conductivity of the tetragonal LLZO film was $4.2 \times 10^{-6} \mathrm{~S} \mathrm{~cm}^{-1}$ at $298 \mathrm{~K}_{\text {with }}$ an activation energy of $0.50 \mathrm{eV}$, which was in good agreement with bulk ceramics tetragonal LLZO. In addition, the study presented that the deposition temperature and oxygen partial pressure had great effect on the quality of the LLZO film. In the condition of $973 \mathrm{~K}$ and $40 \% \mathrm{O}_{2}$, the film, in Figure 5a, showed homogeneous, high density and free of cracks. Figure 5b displayed the Arrhenius plot in the temperature range from $338 \mathrm{~K}$ to $298 \mathrm{~K}$ for the total Li-ion conductivity of the LLZO film. An exponential fit (black line) is applied to the data (red rhombs). 
(a)
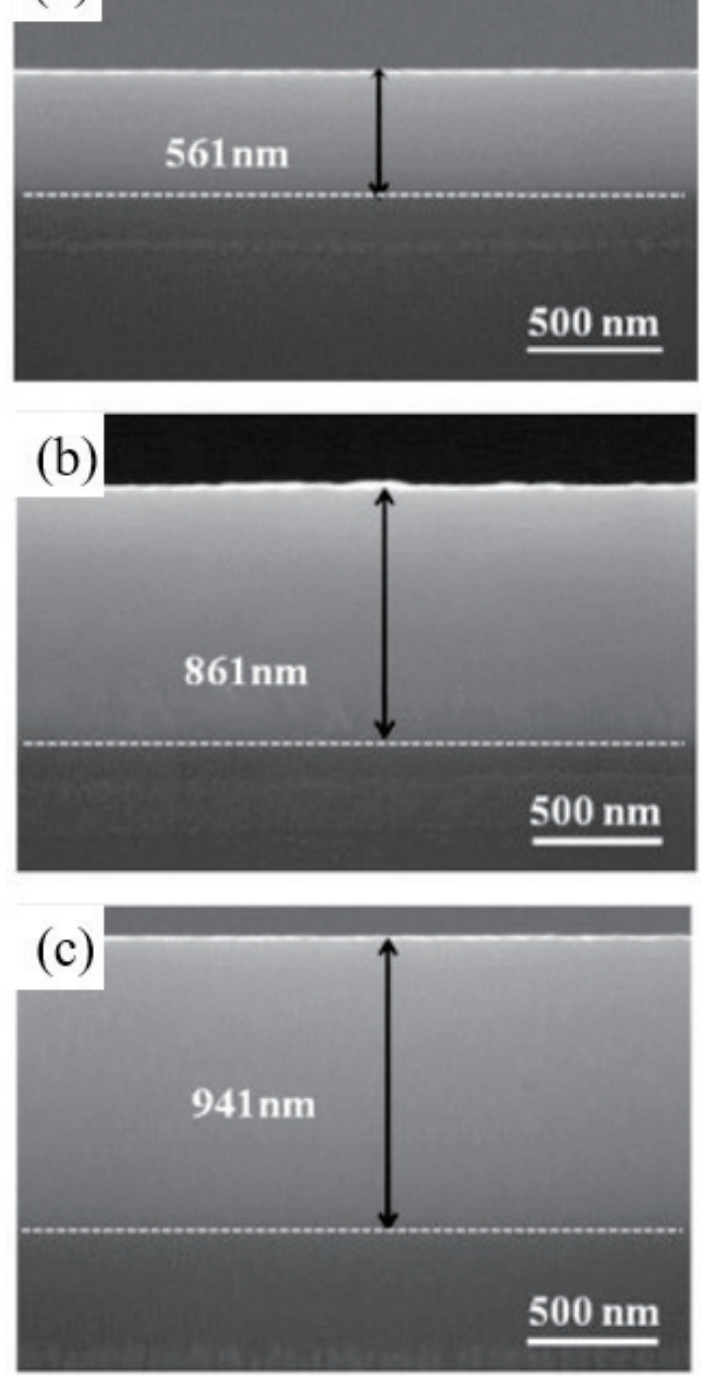

(d)

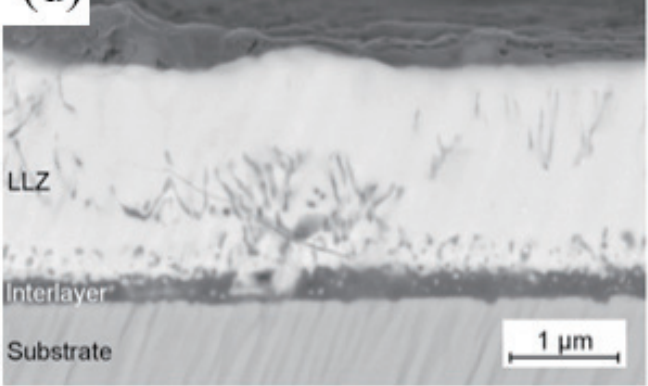

(e)
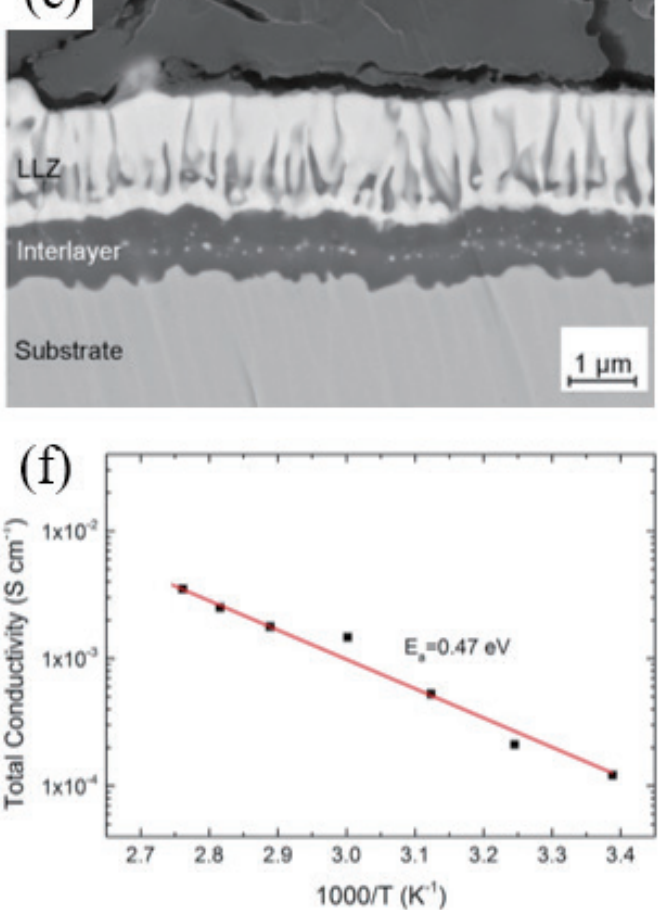

Figure 3. SEM images of the cross section (a, b, c) ${ }^{[69]}$ of $\mathrm{Li}-\mathrm{La}-\mathrm{Zr}-\mathrm{O}$ thin films deposited at $40 \mathrm{~W}$ (a), $60 \mathrm{~W}$ (b) and $80 \mathrm{~W}$ (c); (d)-(e) Microstructure of the thin films deposited at $700^{\circ} \mathrm{C}$ and $800^{\circ} \mathrm{C}{ }^{[70]}(\mathrm{d})$ cross-section, BSE-image, $700^{\circ} \mathrm{C},(\mathrm{e})$ cross-section, BSE-image, 800 ${ }^{\circ} \mathrm{C}$; (f) Impedance data of thin film deposited at $700^{\circ} \mathrm{C}$, Li-ion conductivity $\sigma$ in dependence of temperature $\mathrm{T}$.

Table 2. Review of the literature on garnet type film by the RF technique with an outline of the material, year, substrate, thickness, room temperature ionic conductivity and activation energy

\begin{tabular}{|c|c|c|c|c|c|c|}
\hline Material & Year & Substrate & Thickness & $R T \sigma_{\mathrm{Li}}\left[\mathrm{S} \mathrm{cm}^{-1}\right]$ & $\mathbf{E}_{\mathrm{a}}[\mathrm{eV}]$ & Ref. \\
\hline \multirow{4}{*}{ Li-La-Zr-O } & \multirow{3}{*}{2012} & \multirow{3}{*}{$\mathrm{Si} / \mathrm{SiO}_{2}$ wafer } & $561 \mathrm{~nm}$ & $4 \times 10^{-7}$ & 0.7 & [69] \\
\hline & & & $861 \mathrm{~nm}$ & $2 \times 10^{-7}$ & 0.81 & \multirow{4}{*}{ [70] } \\
\hline & & & \multirow[t]{2}{*}{$941 \mathrm{~nm}$} & $0.8 \times 1^{0-7}$ & 0.87 & \\
\hline & & & & $1.2 \times 10^{-4}($ in-plane $)$ & 0.47 & \\
\hline $\mathrm{Li}_{7} \mathrm{La}_{3} \mathrm{Zr}_{2} \mathrm{O}_{12}$ & 2016 & Stainless steel & $\sim 1 \mu \mathrm{m}$ & $\begin{array}{c}2.0 \times 10^{-9} \text { (perpendicular to the } \\
\text { plane) }\end{array}$ & & \\
\hline
\end{tabular}




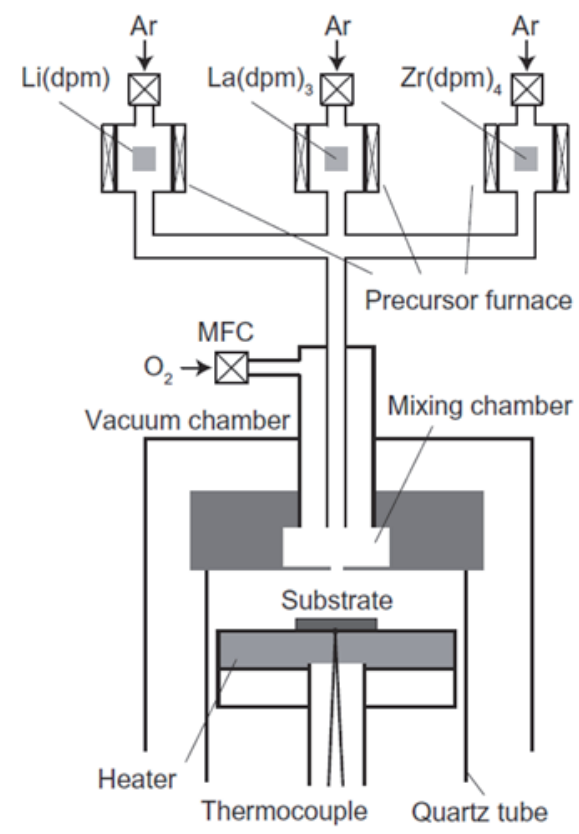

Figure 4. Schematic of a cold wall type MOCVD apparatus ${ }^{[7]}$
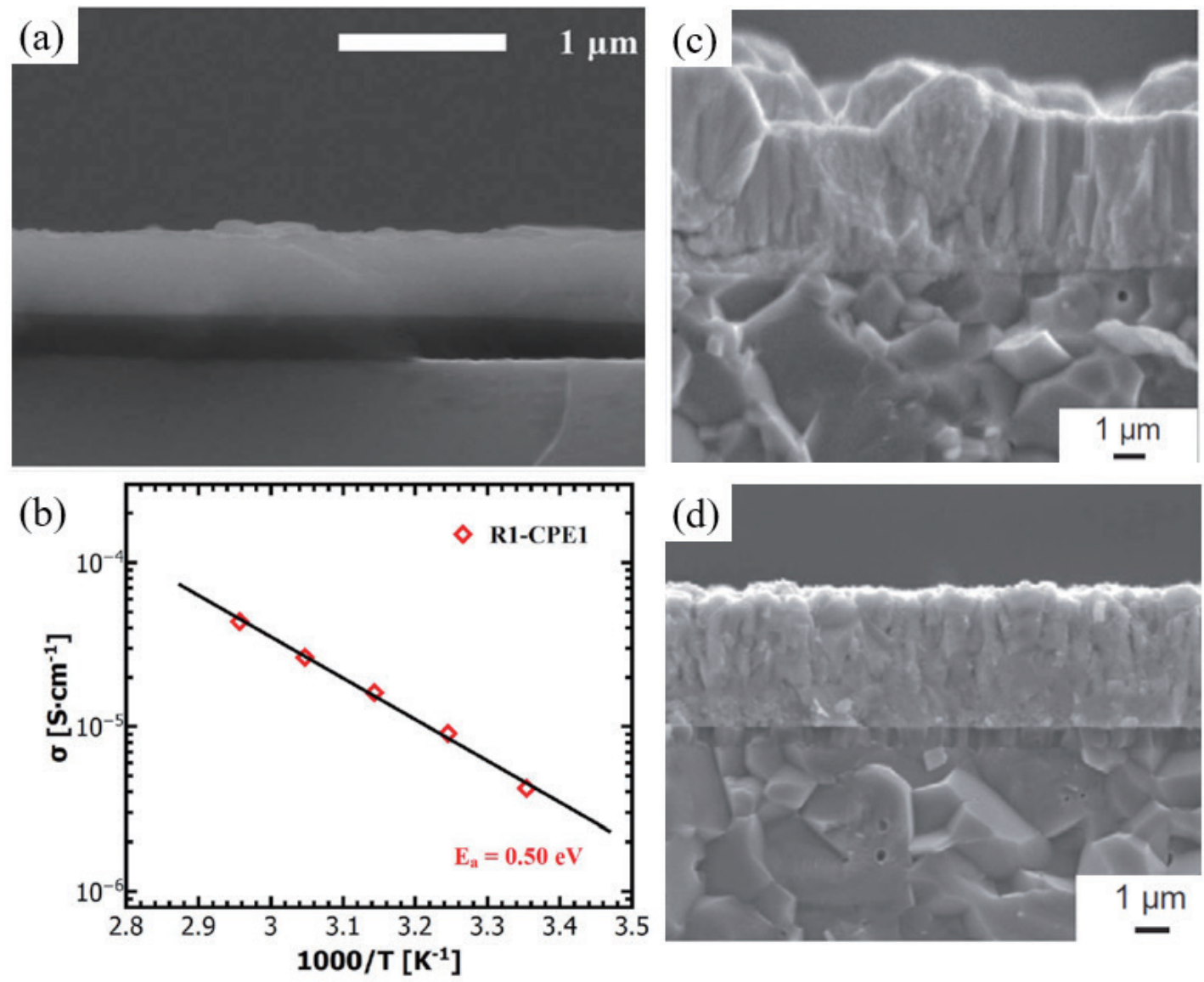

Figure 5. (a) Secondary electron micrographs of LLZO thin films deposited at $973 \mathrm{~K}$ and $40 \% \mathrm{O}_{2}$ on $\mathrm{Si}$, shows the LLZO cross section ${ }^{[72]}$; (b) Arrhenius plot in the temperature range from $338 \mathrm{~K}$ to $298 \mathrm{~K}^{1721}$ (c)-(d) SEM images for $\mathrm{Li}-\mathrm{La}-\mathrm{Zr}-\mathrm{O}$ films ${ }^{171}$; Cross-sectional morphologies of the tetragonal $\mathrm{Li}_{7} \mathrm{La}_{3} \mathrm{Zr}_{2} \mathrm{O}_{12}$ at $1073 \mathrm{~K}$ (c) and cubic $\mathrm{Li}_{7} \mathrm{La}_{3} \mathrm{Zr}_{2} \mathrm{O}_{12}$ at $1223 \mathrm{~K}$ (d) are also included 
Table 3. Review of the literature on garnet type film by CVD technique with an outline of the material, year, substrate, thickness, room temperature ionic conductivity and activation energy

\begin{tabular}{|c|c|c|c|c|c|c|}
\hline Material & Year & Substrate & Thickness & $R T \sigma_{\mathrm{Li}}\left[\mathrm{S} \mathrm{cm} \mathrm{cm}^{-1}\right]$ & $\mathbf{E}_{\mathrm{a}}[\mathrm{eV}]$ & Ref. \\
\hline $\mathrm{Li}_{7} \mathrm{La}_{3} \mathrm{Zr}_{2} \mathrm{O}_{12}$ & 2017 & $\mathrm{Pt}$ & $850 \mathrm{~nm}$ & $4.2 \times 10^{-6}$ & 0.5 & [73] \\
\hline $\mathrm{Li}_{7} \mathrm{La}_{3} \mathrm{Zr}_{2} \mathrm{O}_{12}$ & 2015 & Poly- $\mathrm{Al}_{2} \mathrm{O}_{3}$ & $\sim 1 \mu \mathrm{m}$ & - & - & [74] \\
\hline
\end{tabular}

\subsection{Atomic layer deposition (ALD)}
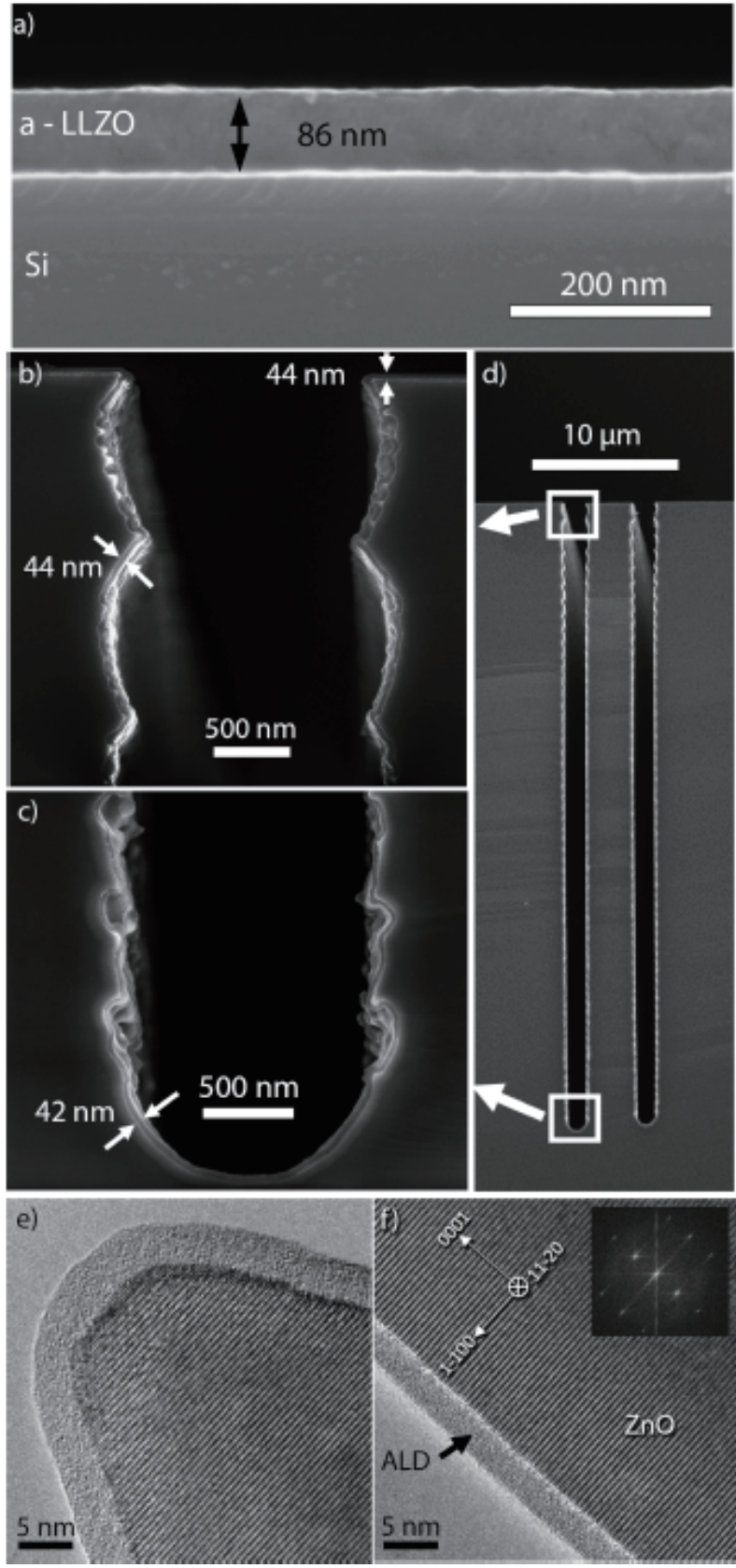

Figure 6. (a) SEM image showing as-deposited ALD LLZO film on a Si substrate, (b) SEM image showing the ALD film from the top of a Si trench shown in (c), (d) SEM image showing the ALD coating at the bottom of a Si trench, (e) TEM image showing the ultrathin conformal coating at the tip of a $\mathrm{ZnO}$ nanowire, and (f) TEM image showing a sharp film/wire interface, with electron diffraction (inset) showing the amorphous nature of film ${ }^{17}$

In the field of battery research, atomic layer deposition (ALD) has its applications in preparing electrode materials. 
Atomic layer deposition provides an exciting opportunity for functional barrier layers in perovskite solar cells. Bent et al. ${ }^{[75]}$ prepared an $\mathrm{ALD} \mathrm{SnO}_{2}$ contact layer as a "built-in" barrier layer on $\mathrm{C}_{60}$ dramatically improves device stability over typical p-i-n devices with only organic electron transport layers, which resulted in superior barrier properties. In the field of lithium ion battery, Zhang et al. ${ }^{[76]}$ prepared the modified the $\mathrm{LiNi}_{0.8} \mathrm{Mn}_{0.1} \mathrm{Co}_{0.1} \mathrm{O}_{2}(\mathrm{NMC} 811)$ cathode by coating and subsequent infusion of the LPO solid-state electrolyte along the grain boundaries of secondary particles by atomic layer deposition. And the result demonstrated that the modified NMC811 layered cathode by ALD method can significantly enhance its structural and interfacial stability, and lead to the long-term cycle stability of both capacity and voltage. Atomic layer deposition has been applied to be a powerful technique for interfacial modification of $\mathrm{Li}$-ion and Li-metal electrodes and for the deposition of solid electrolytes in complex 3D architectures ${ }^{[77]}$. Kazyak et al. ${ }^{[77]}$ demonstrated a viable ALD process for depositing Al-doped $\mathrm{LLZO}\left(\mathrm{Li}_{6.28} \mathrm{La}_{3} \mathrm{Zr}_{2} \mathrm{O}_{12} \mathrm{Al}_{0.24}\right)$ films with a low amount of impurities, tunable composition, and self-limiting behavior. The film, Figure 6a, was prepared on the $\mathrm{Si}\left(\begin{array}{lll}1 & 0 & 0\end{array}\right)$ substrate at a scale of $86 \mathrm{~nm}$. In addition, ALD showed a good ability to deposit LLZO films on 3D-structured substrates, such as Si wafer in Figure 6b-6d and single-crystal $\mathrm{ZnO}$ nanowires in Figure 6e-6f. The Al-doped stoichiometric film had an ionic conductivity of $7.8 \times 10^{-5} \mathrm{~S}$ $\mathrm{cm}^{-1}$ at $200{ }^{\circ} \mathrm{C}$ and $1.2 \times 10^{-6} \mathrm{~S} \mathrm{~cm}^{-1}$ at $100{ }^{\circ} \mathrm{C}$, giving an activation energy of $0.63 \mathrm{eV} /$ atom and a calculated conductivity of approximately $1 \times 10^{-8} \mathrm{~S} \mathrm{~cm}^{-1}$ at $25^{\circ} \mathrm{C}^{[77]}$.

\subsection{Aerosol deposition (AD) method}

Aerosol deposition (AD) films can be formed at room temperature and show dense microstructures having no annealing process which avoided the reaction between electrolytes and active materials. Figure 7 exhibited the apparatus and the schematic diagram of AD process.

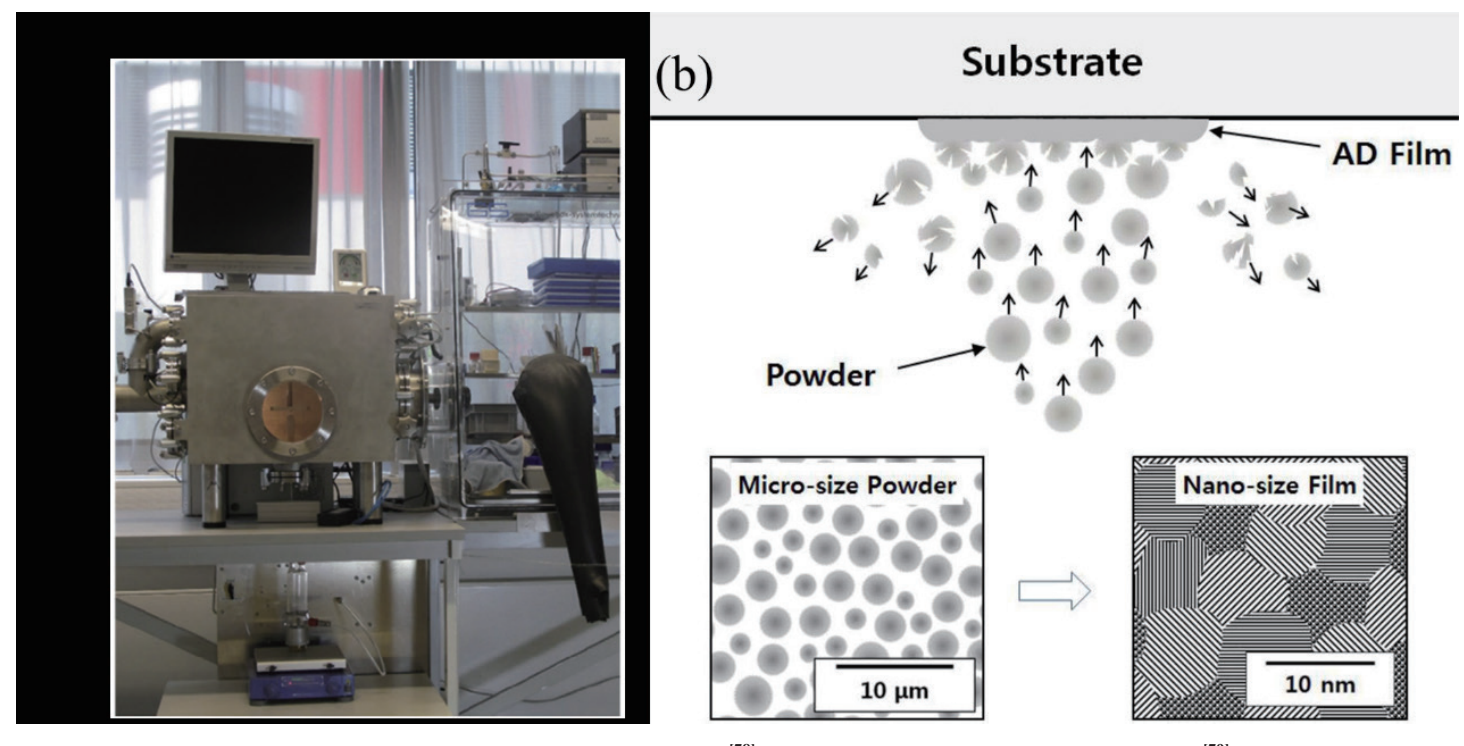

Figure 7. (a) Apparatus of AD process ${ }^{[78]}$ (b) Schematic diagram of AD process ${ }^{[79]}$

Hanft et al. ${ }^{[78]}$ fabricated a cubic garnet solid electrolyte $\mathrm{Al}_{\mathrm{y}} \mathrm{Li}_{7-3 \mathrm{y}-\mathrm{z}} \mathrm{La}_{3} \mathrm{Zr}_{2-\mathrm{z}} \mathrm{Ta}_{\mathrm{z}} \mathrm{O}_{12}$ (ALLZTO) by the aerosol deposition method. The as-deposited films in figure 8a showed a thickness of $\sim 10 \mu \mathbf{m}$ and a reduced conductivity around $2.0 \times 10^{-7}$ $\mathrm{S} \mathrm{cm}^{-1}$. They studied a thermal post-treatment of the film, which revealed the morphological and the related impact on the ionic conductivity. According to the results, the film showed an ionic conductivity of $2.0 \times 10^{-5} \mathrm{~S} \mathrm{~cm}^{-1}$ at $400{ }^{\circ} \mathrm{C}$ and $7.0 \times$ $10^{-5} \mathrm{~S} \mathrm{~cm}^{-1}$ at $600{ }^{\circ} \mathrm{C}$.

Ahn et al. ${ }^{[79]}$ investigated the microstructure and ionic conductivity of LLZO aerosol deposition film. Figure $\mathbf{8 b}$ showed the SEM of the raw LLZO powder and the prepared LLZO AD film. In figure 8b, The LLZO aerosol deposition film, with a thickness of $20 \mu \mathbf{m}$, showed the dense microstructure which had nano-size grains. However, the ionic conductivity was $1.0 \times 10^{-8} \mathrm{~S} \mathrm{~cm}^{-1}$ at $140^{\circ} \mathrm{C}$. 
(a)
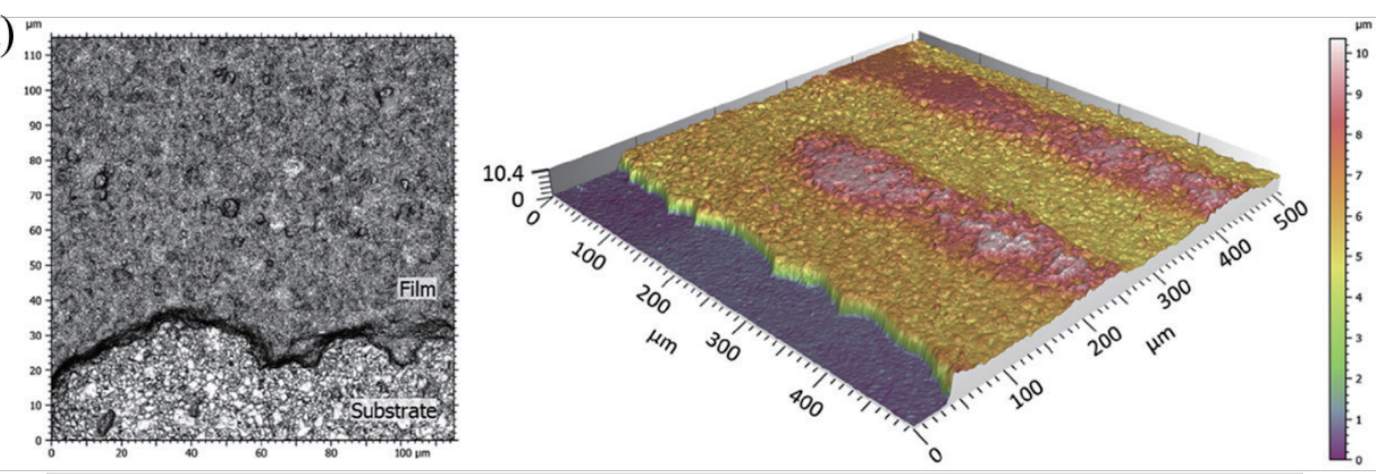

(b)
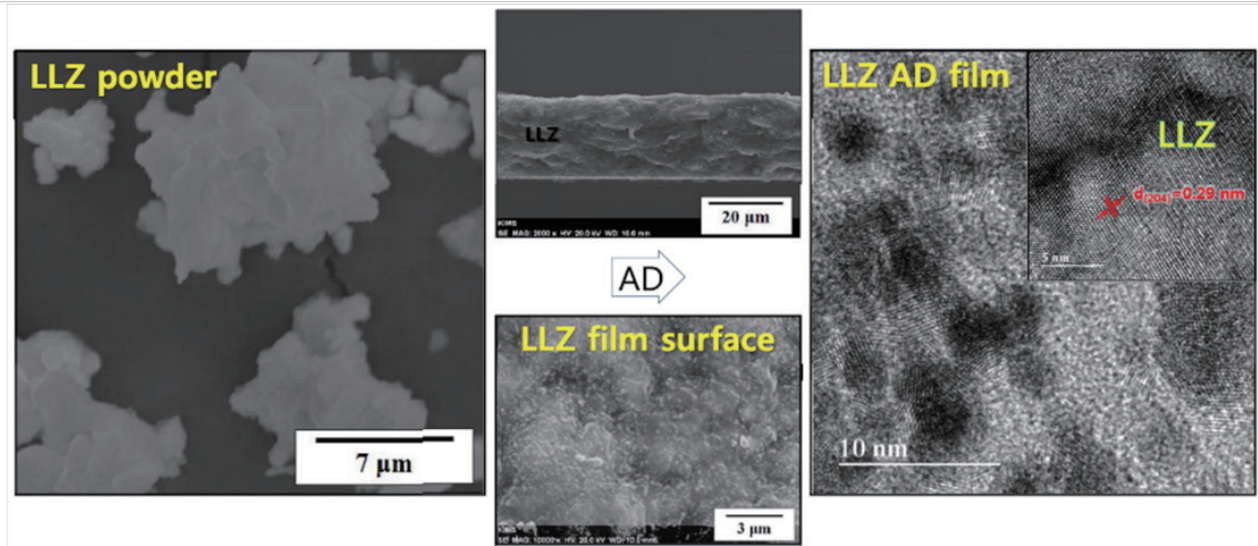

Figure 8. (a) 3D-Laser-Scanning image of ALLZTO film ${ }^{[78]}$ (b) SEM and TEM images of LLZO powder and AD film ${ }^{[79]}$

\section{Sol-gel method}

With the harsh vacuum condition, compared with pulsed laser deposition and radio frequency, sol-gel method exhibits lots advantages on low cost, easy synthesis and flexible chemical components.

In the year of 2014 , Chen et al. ${ }^{[80]}$ prepared Li-La-Zr-O film on the Si substrate by a sol-gel spin coating method. In the work, they studied the effects of the annealing temperature and the number of layers on ionic conductivity of the films. With the annealing temperature increased from $600{ }^{\circ} \mathrm{C}$ to $800{ }^{\circ} \mathrm{C}$, the ionic conductivity of the films decreased from $1.67 \times 10^{-6} \mathrm{~S} \mathrm{~cm}^{-1}$ to $8.53 \times 10^{-7} \mathrm{~S} \mathrm{~cm}^{-1}$. The thickness of the films could be controlled by the number of layers. Figure $9 \mathrm{a}$ was the SEM images of cross section Li-La-Zr-O thin films with different layers. According to the result, by adding the layer from 2 to 12, the thickness increased from $130 \mathrm{~nm}$ to $538 \mathrm{~nm}$.

Through a sol-gel dip-coating process, on the substrate of $\mathrm{MgO}$, Tadanaga et al. ${ }^{[79]}$ fabricated $\mathrm{Al}$ doped $\mathrm{Li}_{7} \mathrm{La}_{3} \mathrm{Zr}_{2} \mathrm{O}_{12}$ using a precursor sol from $\mathrm{Zr}$-alkoxide and Li, La and Al nitrates. After the heat-treatment at $900{ }^{\circ} \mathrm{C}$, the LLZO film showed an ionic conductivity of $2.4 \times 10^{-6} \mathrm{~S} \mathrm{~cm}^{-1}$.

Zarabian et al. ${ }^{[82]}$ prepared Li-La-Zr-O film by sol-gel spin-coating method at a lower annealing temperature on 400 ${ }^{\circ} \mathrm{C}$. The film was fabricated on the top surface of $\mathrm{MgO}(100)$ and $\mathrm{LiCoO}_{2}$ pellets. The thickness of the films was $760 \mathrm{~nm}$ on the substrate of $\mathrm{MgO}(100)$ and $3606.4 \mathrm{~nm}$ on the $\mathrm{LiCoO}_{2}$ pellets, which was in Figure 9b and 9c The X-ray photoelectron spectroscopy analysis of the interface between $\mathrm{LiCoO}_{2}$ and $\mathrm{Li}-\mathrm{La}-\mathrm{Zr}-\mathrm{O}$ film showed that Co diffuses from the substrate toward the solid electrolyte. 
(a)
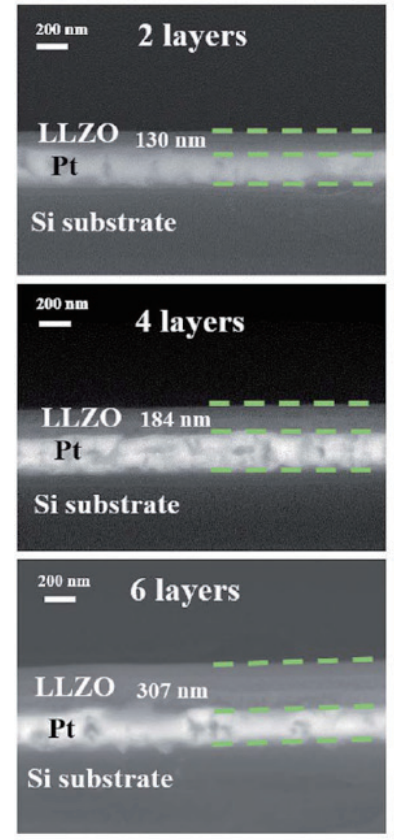

(b)

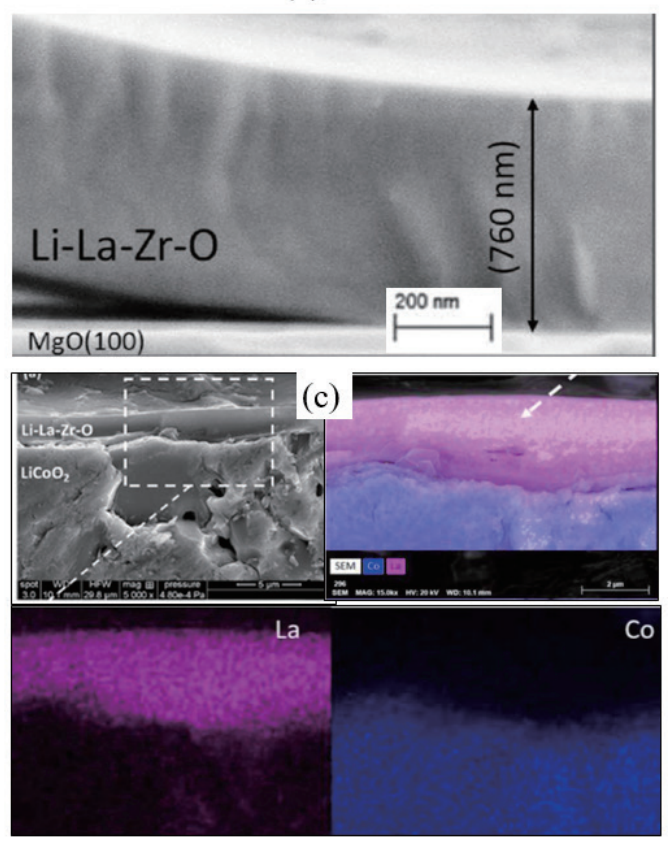

Figure 9. (a) SEM images of cross section Li-La-Zr-O thin films with different layers ${ }^{[80]}$; (b)cross section SEM image of a broken layer shows dense and crack-free layer on $\mathrm{MgO}^{[82]}$; (c)SEM cross section image of $\mathrm{Li}$ - $\mathrm{La}-\mathrm{Zr}-\mathrm{O}$ on $\mathrm{LiCoO}_{2}$ substrate, along with mapping, showing dense electrolyte ${ }^{[82]}$

Table 4. Review of the literature on garnet type film by sol-gel technique with an outline of the material, year, substrate, thickness, room temperature ionic conductivity and activation energy

\begin{tabular}{|c|c|c|c|c|c|c|}
\hline Material & Year & Substrate & Thickness & $R T \sigma_{\mathrm{Li}}\left[\mathrm{S} \mathrm{cm}^{-1}\right]$ & $\mathbf{E}_{\mathrm{a}}[\mathrm{eV}]$ & Ref. \\
\hline & & & & $1.67 \times 10^{-6}$ at $600^{\circ} \mathrm{C}$ & $0.18-0.21$ & {$[83]$} \\
\hline \multirow[t]{2}{*}{ Li-La-Zr-O } & 2014 & $\mathrm{Si}$ & $130-538 \mathrm{~nm}$ & & & \\
\hline & & & & $8.53 \times 10^{-7}$ at $800^{\circ} \mathrm{C}$ & & \\
\hline $\mathrm{Al}-\mathrm{Li}_{7} \mathrm{La}_{3} \mathrm{Zr}_{2} \mathrm{O}_{12}$ & 2015 & $\mathrm{MgO}$ & - & $2.4 \times 10^{-6}$ & - & [84] \\
\hline Li-La-Zr-O & 2017 & $\mathrm{MgO}$ & $760 \mathrm{~nm}$ & - & 0.6 & [85] \\
\hline
\end{tabular}

\section{Focused ion beam (FIB) milling}

Focused ion beam milling is another way to prepare LLZO thin film. Gong et al. ${ }^{[86]}$ reported a method by in-situ atomic-scale observation of electrochemical delithiation in all-solid-state battery. They constructed an all-solid-state LIB with a gold anode, a $\mathrm{LiCoO}_{2}$ cathode, and $\mathrm{Y}$ and Ta doped $\mathrm{LLZO}\left(\mathrm{Li}_{6.75} \mathrm{La}_{2.84} \mathrm{Y}_{0.16} \mathrm{Zr}_{1.75} \mathrm{Ta}_{0.25} \mathrm{O}_{12}\right)$ as the solid-state electrolyte (thickness less than $2 \mu \mathrm{m}$ ) on a micro-electro-mechanical system (MEMS) device nano-chip using FIB milling (in Figure 10). Compared with the performance in liquid electrolyte batteries, they found that the pristine single crystal $\mathrm{LiCoO}_{2}$ became nano-sized polycrystal connected by coherent twin boundaries and antiphase domain boundaries after high voltage delithiation ${ }^{[86]}$.

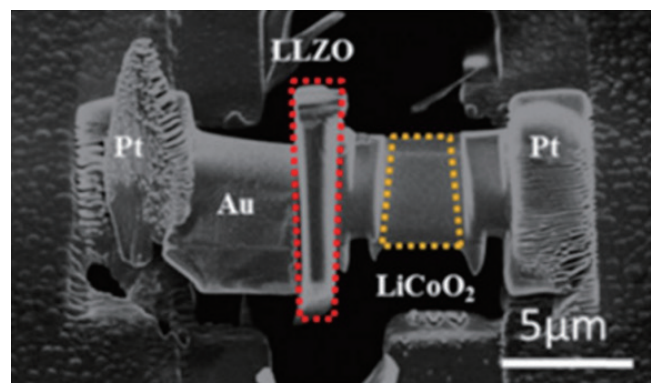

Figure 10. SEM image of the FIB fabricated battery on the nanochip to apply the electric field ${ }^{[86]}$ 


\section{Composite electrolyte thin film}

Due to the inherent characteristics, harsh preparation condition or some other reasons, none of the LLZO films, prepared by the methods in the above sections, has no applications or play a role in all solid state battery. This section highlights the LLZO composite electrolyte film, which has already come into use in ASSB.

The ionic conductivity of composite electrolyte was enhanced greatly after adding LLZO nano-particles or nanowires, because the adding nano-sized LLZO took place in decreasing the crystallinity of polymer ${ }^{[87-89]}$ and in providing more lithium ion pathway ${ }^{[90-93]}$. In addition, Liu et al. ${ }^{[94]}$ found that well-aligned LLZO nanowires enhanced the ionic conductivity effectively. Zhang et al. ${ }^{[95]}$ discussed the role of LLZO particles size on improving the conductivity. Mass of LLZO composite electrolytes have applied in all-solid-state battery ${ }^{[96-100]}$. According to the results, the thickness of LLZO composite electrolyte film was in the range from dozens to hundreds micron. For example: the work ${ }^{[95]}$ of PEO:LLZTO membrane electrolytes showed a thickness of $40 \mu \mathrm{m}$, with an ionic conductivities of $2.1 \times 10^{-4} \mathrm{~S} \mathrm{~cm}^{-1}$ at $30^{\circ} \mathrm{C}$ and $5.6 \times 10^{-}$ ${ }^{4} \mathrm{~S} \mathrm{~cm}^{-1}$ at $60^{\circ} \mathrm{C}$. The film showed good rate capability and cycle performance both with LFPO and LFMP-based cathodes. Chen et al. ${ }^{[97]}$ fabricated a LLZTO composite membrane of $70 \mu \mathrm{m}$ thickness by hot pressing without any organic solvent. The $\mathrm{LiFePO}_{4} / \mathrm{Li}$ batteries with"polymer-in-ceramic" electrolyte PEO-LLZTO-PEG-60 wt\% LiTFSI delivered excellent cycling stability.

Yan et al. ${ }^{[101,102]}$ introduced an easy method of tape casting the nano-particle slurry to prepare LLZO film with the thickness of several micrometers. The schematic illustration, in Figure 11a, showed all the steps of the process. The thickness of the film was about $3 \mu \mathrm{m}$ according to the SEM images in Figure 11c and 11d. The ionic conductivity of film, showed in Figure $11 \mathrm{~b}$, was $5.55 \times 10^{-6} \mathrm{~S} \mathrm{~cm}^{-1}$ at $20^{\circ} \mathrm{C}$ and $6.96 \times 10^{-5} \mathrm{~S} \mathrm{~cm}^{-1}$ at $100^{\circ} \mathrm{C}$. In the report, the LLZO was used as the solid electrolyte in the Li/LLZO/LFPO battery. As shown in Figure 11e, the cell showed a discharge capacity of $136.8 \mathrm{mAh} \mathrm{g}^{-1}$ after 100 cycles at a rate of $0.1 \mathrm{C}$ at room temperature. In Figure 11f, at $60{ }^{\circ} \mathrm{C}$, the cell showed a discharge capacity of $146.2 \mathrm{mAh} \mathrm{g}^{-1}$ after 100 cycles at $0.1 \mathrm{C}$, which was $99.4 \%$ of the second cycle. In addition, the LLZO film was also applied in the cell of Li/LLZO/LCO. Figure 11g and Figure 11h showed the surface and the section of solid electrolyte and cathode layer. The cycling performance of Li/LLZO/LCO at different rates was shown in Figure 11i.
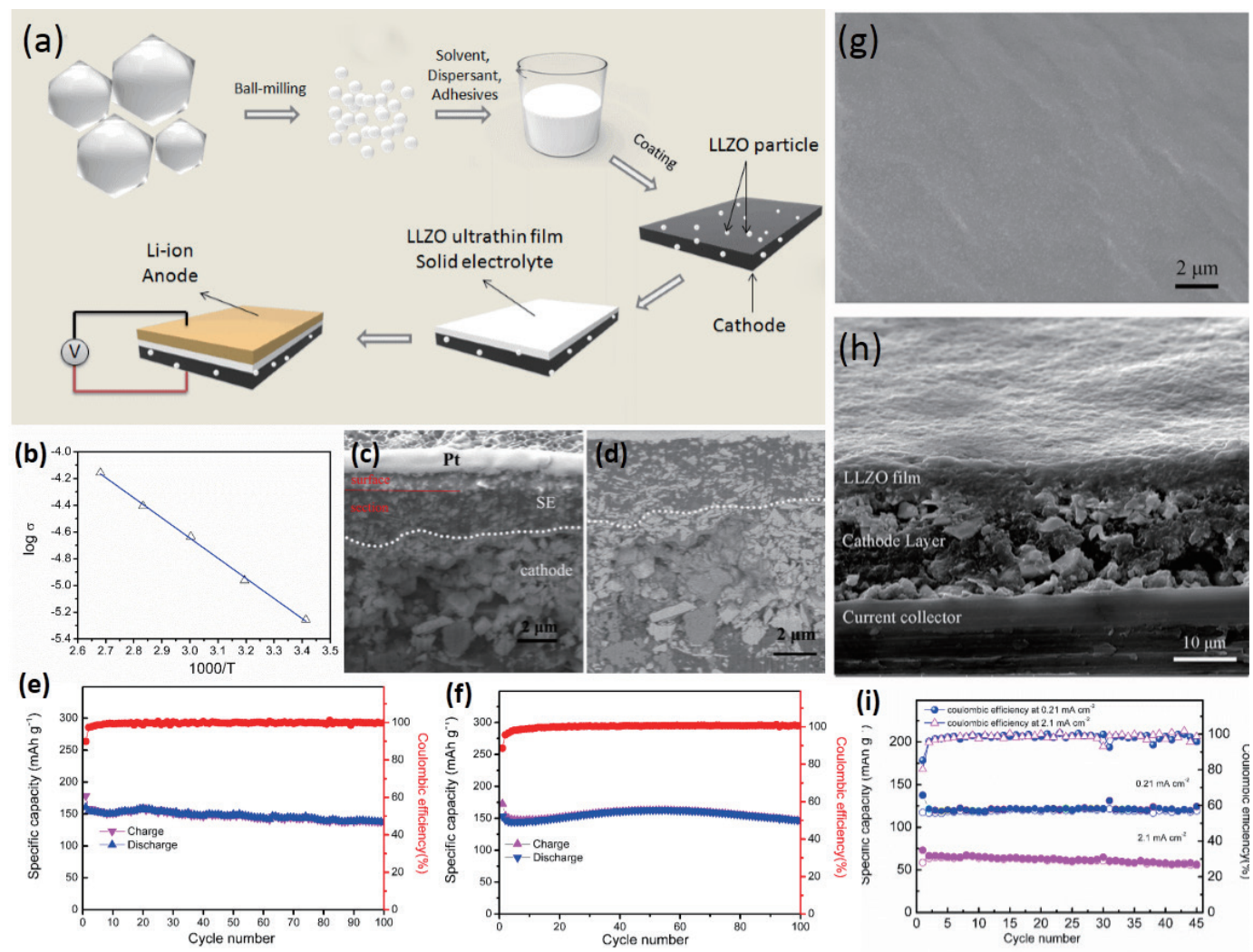

Figure 11. (a) Schematic illustration of the synthesis procedure; (b) Arrhenius conductivity plots of LLZO film; (c) The SEM of the section of LFPO cathode layer and LLZO film; (d) The ESB of the section of LFPO cathode layer and LLZO film; (e) cycling performance and coulombic efficiency of $\mathrm{Li} / \mathrm{LLZO} / \mathrm{LFPO}$ at room temperature; (f) cycling performance and coulombic efficiency of $\mathrm{Li} / \mathrm{LLZO} / \mathrm{LFPO}$ at $60^{\circ} \mathrm{C}$; (a)-(f) in the reference ${ }^{[101]}$ (g)-(i) in the reference(g) The SEM of the surface of LLZO film; (h) The SEM image of the section of cathode layer and LLZO film; (i) cycling performance and coulombic efficiency of $\mathrm{Li} / \mathrm{LLZO} / \mathrm{LCO}^{[\mathrm{fr2} \mid}$ 


\section{Summary and perspectives}

In conclusion, different methods have been developed to prepare LLZO films by now. According to the results and data summarized in above sections, different methods have their own pros and cons. Deposition methods shows the advantages in thickness of LLZO film. Especially, the films prepared by PLD and ALD show the best results. The technique of RF has the highlight of controlling the thickness of film by changing the power. The film obtained by deposition method is as thin as in nanoscale. But deposition methods have disadvantages in harsh preparation condition, such as: vacuum condition and substrate condition. Sol-gel method is an easy synthesis and low cost way to fabricate LLZO film, no matter the substrate conditions. But the method has the weakness on the substrate condition and very longperiod experiment. The method of tape casting LLZO shows a simple operation and easy synthesis. But the films obtained by this method are thicker than by other methods.

According to the update reports, LLZO film-electrolytes have inferior ionic conductivity compared with bulk ceramic electrolyte. However, LLZO film- electrolytes, especially for the ultrathin film, have the inherent advantages due to the thickness. With the increasing demand for the micro-sized power source and the development of the fabricating technique, the film type electrolytes will be better and further improved.

\section{Acknowledgement}

This research did not receive any specific grant from funding agencies in the public, commercial, or not-for-profit sectors.

\section{References}

[1] Ramakumar, S Deviannapoorani, C Dhivya, L, et al. Lithium garnets: Synthesis, structure, $\mathrm{Li}^{+}$conductivity, $\mathrm{Li}^{+}$ dynamics and applications. Progress in Materials Science. 2017; 88: 325-411.

[2] Chen, R Qu, W Guo, X, et al. The pursuit of solid-state electrolytes for lithium batteries: from comprehensive insight to emerging horizons. Mater. Horiz. 2016; 3: 487-516.

[3] Ting, Yang Jin, Zheng Qian, Cheng et al. Composite Polymer Electrolytes with $\mathrm{Li}_{7} \mathrm{La}_{3} \mathrm{Zr}_{2} \mathrm{O}_{12}$ Garnet-Type Nanowires as Ceramic Fillers: Mechanism of Conductivity Enhancement and Role of Doping and Morphology. NATURE. 2001; 414: 359-367.

[4] Li, W, . Dahn, J RWainwright, D S. Rechargeable lithium batteries with aqueous electrolytes. Science. 1994; 264 (5162): 1115-1118.

[5] Tatsumisago, M Nagao, MHayashi, A. Recent development of sulfide solid electrolytes and interfacial modification for all-solid-state rechargeable lithium batteries. Journal of Asian Ceramic Societies. 2013.1(1),17-25.

[6] Kim, T-H Park, J-S Chang, S K, et al. The Current Move of Lithium Ion Batteries Towards the Next Phase. Advanced Energy Materials. 2012; 2 (7): 860-872.

[7] Zhou, G Li, F Cheng, H-M. Progress in flexible lithium batteries and future prospects. Energy Environ. 2014; 7 (4): 1307-1338.

[8] M. Armand, J-M T. Building better batteries. NATURE. 2008; 451: 652-657.

[9] Xu, K. Electrolytes and interphases in Li-ion batteries and beyond. Chem Rev. 2014; 114 (23): 11503-11618.

[10] Thangadurai, V Narayanan, SPinzaru, D. Garnet-type solid-state fast Li ion conductors for Li batteries: critical review. Chem Soc Rev. 2014; 43 (13): 4714-4727.

[11] Kamaya, N Homma, K Yamakawa, Y, et al. A lithium superionic conductor. Nat Mater. 2011; 10 (9): 682-686.

[12] Kato, Y Hori, S Saito, T, et al. High-power all-solid-state batteries using sulfide superionic conductors. Nature Energy. 2016; 1 (4): 16030.

[13] Jin, YMcGinn, P J. $\mathrm{Li}_{7} \mathrm{La}_{3} \mathrm{Zr}_{2} \mathrm{O}_{12}$ electrolyte stability in air and fabrication of a $\mathrm{Li} / \mathrm{Li}_{7} \mathrm{La}_{3} \mathrm{Zr}_{2} \mathrm{O}_{12} / \mathrm{Cu}_{0.1} \mathrm{~V}_{2} \mathrm{O}_{5}$ solid-state battery. Journal of Power Sources. 2013; 239: 326-331.

[14] Wu, J F Pang, W K Peterson, V K, et al. Garnet-Type Fast Li-Ion Conductors with High Ionic Conductivities for AllSolid-State Batteries. ACS Appl Mater Interfaces. 2017; 9 (14): 12461-12468.

[15] Li, Y Wang, Z Cao, Y, et al. W-Doped $\mathrm{Li}_{7} \mathrm{La}_{3} \mathrm{Zr}_{2} \mathrm{O}_{12}$ Ceramic Electrolytes for Solid State Li-ion Batteries. Electrochimica Acta. 2015; 180: 37-42.

[16] Liu, T Ren, Y Shen, Y, et al. Achieving high capacity in bulk-type solid-state lithium ion battery based on $\mathrm{Li}_{6.75} \mathrm{La}_{3} \mathrm{Zr}_{1.75} \mathrm{Ta}_{0.25} \mathrm{O}_{12}$ electrolyte: Interfacial resistance. Journal of Power Sources. 2016; 324: 349-357.

[17] Shin, R-H Son, S I Han, Y S, et al. Sintering behavior of garnet-type $\mathrm{Li}_{7} \mathrm{La}_{3} \mathrm{Zr}_{2} \mathrm{O}_{12}-\mathrm{Li}_{3} \mathrm{BO}_{3}$ composite solid electrolytes for all-solid-state lithium batteries. Solid State Ionics. 2017; 301: 10-14. 
[18] Li, Y Wang, Z Li, C, et al. Densification and ionic-conduction improvement of lithium garnet solid electrolytes by flowing oxygen sintering. Journal of Power Sources. 2014; 248 (4): 642-646.

[19] Suzuki, Y Kami, K Watanabe, K, et al. Transparent cubic garnet-type solid electrolyte of $\mathrm{Al}_{2} \mathrm{O}_{3}$-doped $\mathrm{Li}_{7} \mathrm{La}_{3} \mathrm{Zr}_{2} \mathrm{O}_{12}$. Solid State Ionics. 2015; 278: 172-176.

[20] Choudhury, S Mangal, R Agrawal, A, et al. A highly reversible room-temperature lithium metal battery based on crosslinked hairy nanoparticles. Nat Commun. 2015; 6: 10101.

[21] Zhang, J Zhao, J Yue, L, et al. Safety-Reinforced Poly(Propylene Carbonate)-Based All-Solid-State Polymer Electrolyte for Ambient-Temperature Solid Polymer Lithium Batteries. Advanced Energy Materials. 2015; 5 (24): 1501082.

[22] Yada, C Ohmori, A Ide, K, et al. Dielectric Modification of 5V-Class Cathodes for High-Voltage All-Solid-State Lithium Batteries. Advanced Energy Materials. 2014; 4 (9): 1301416.

[23] Ohta, N Takada, K Sakaguchi, I, et al. $\mathrm{LiNbO} 3$-coated $\mathrm{LiCoO}_{2}$ as cathode material for all solid-state lithium secondary batteries. Electrochemistry Communications. 2007; 9 (7): 1486-1490.

[24] Sakuda, A Hayashi, ATatsumisago, M. Interfacial Observation between $\mathrm{LiCoO}_{2}$ Electrode and $\mathrm{Li}_{2} \mathrm{~S}_{-} \mathrm{P}_{2} \mathrm{~S}_{5}$ Solid Electrolytes of All-Solid-State Lithium Secondary Batteries Using Transmission Electron Microscopy. Chemistry of Materials. 2010; 22 (3): 949-956.

[25] Miara, L J Richards, W D Wang, Y E, et al. First-Principles Studies on Cation Dopants and Electrolyte|Cathode Interphases for Lithium Garnets. Chemistry of Materials. 2015; 27 (11): 4040-4047.

[26] Allen, J L Wolfenstine, J Rangasamy, E, et al. Effect of substitution (Ta, Al, Ga) on the conductivity of $\mathrm{Li}_{7} \mathrm{La}_{3} \mathrm{Zr}_{2} \mathrm{O}_{12}$. Journal of Power Sources. 2012; 206 (1): 315-319.

[27] Rettenwander, D Geiger, C AAmthauer, G. Synthesis and Crystal Chemistry of the Fast Li-Ion Conductor $\mathrm{Li}_{7} \mathrm{La}_{3} \mathrm{Zr}_{2} \mathrm{O}_{12}$ Doped with Fe. Inorganic Chemistry. 2013; 52 (14): 8005-8009.

[28] Hubaud, A A Schroeder, D J Key, B, et al. Low temperature stabilization of cubic $\left(\mathrm{Li}_{7}-{ }_{x} \mathrm{Al}_{\mathrm{x} / 3}\right) \mathrm{La}_{3} \mathrm{Zr}_{2} \mathrm{O}_{12}:$ role of aluminum during formation. Journal of Materials Chemistry. A 2013; 1 (31): 8813-8818.

[29] Inada, R Kusakabe, $\mathrm{K}$ Tanaka, $\mathrm{T}$, et al. Synthesis and properties of $\mathrm{Al}-\mathrm{free} \mathrm{Li}_{7-\mathrm{x}} \mathrm{La}_{3} \mathrm{Zr}_{2-\mathrm{x}} \mathrm{Ta}_{\mathrm{x}} \mathrm{O}_{12}$ garnet related oxides. Solid State Ionics. 2014; 262 (9): 568-572.

[30] Miara, L J Ong, S P Mo, Y, et al. Effect of Rb and Ta Doping on the Ionic Conductivity and Stability of the Garnet $\mathrm{Li}_{7+2 \mathrm{x}-\mathrm{y}}\left(\mathrm{La}_{3-\mathrm{x}} \mathrm{Rb}_{\mathrm{x}}\right)\left(\mathrm{Zr}_{2-\mathrm{y}} \mathrm{Ta}_{\mathrm{y}}\right) \mathrm{O}_{12(0 \leq \mathrm{x} \leq 0.375,0 \leq \mathrm{y} \leq 1)}$ Superionic Conductor: A First Principles Investigation. Chemistry of Materials. 2013; 25 (15): 3048-3055.

[31] Dhivya, L Janani, N Palanivel, B, et al. $\mathrm{Li}^{+}$transport properties of $\mathrm{W}$ substituted $\mathrm{Li}_{7} \mathrm{La}_{3} \mathrm{Zr}_{2} \mathrm{O}_{12}$ cubic lithium garnets. Aip Advances. 2013; 3 (8): 437.

[32] Dhivya, L Murugan, R. Effect of Simultaneous Substitution of Y and Ta on the Stabilization of Cubic Phase, Microstructure, and $\mathrm{Li}+$ Conductivity of $\mathrm{Li}_{7} \mathrm{La}_{3} \mathrm{Zr}_{2} \mathrm{O}_{12}$ Lithium Garnet. Acs Appl Mater Interfaces. 2014; 6 (20): 17606-17615.

[33] Thangadurai, V Pinzaru, D Narayanan, S, et al. Fast Solid-State Li Ion Conducting Garnet-Type Structure Metal Oxides for Energy Storage. J Phys Chem Lett. 2015; 6 (2): 292-299.

[34] Wolfenstine, J Allen, J L. Electron microscopy characterization of hot-pressed Al substituted LiLaZrO. Journal of Materials Science. 2012; 47 (10): 4428-4431.

[35] Rangasamy, E Wolfenstine, JSakamoto, J. The role of Al and Li concentration on the formation of cubic garnet solid electrolyte of nominal composition $\mathrm{Li} 7 \mathrm{La}_{3} \mathrm{Zr}_{2} \mathrm{O}_{12}$. Solid State Ionics. 2012; 206 (1): 28-32.

[36] Zhang, Y Chen, F Rong, T, et al. Field assisted sintering of dense Al-substituted cubic phase $\mathrm{Li}_{7} \mathrm{La}_{3} \mathrm{Zr}_{2} \mathrm{O}_{12}$ solid electrolytes. Journal of Power Sources. 2014; 268 (3): 960-964.

[37] Baek, S W Lee, J M Kim, T Y, et al. Garnet related lithium ion conductor processed by spark plasma sintering for all solid state batteries. Journal of Power Sources. 2014; 249: 197-206.

[38] $\mathrm{Li}$, Y Yang, C Guo, X. Influence of lithium oxide additives on densification and ionic conductivity of garnet-type $\mathrm{Li}_{6.75}$ $\mathrm{La}_{3} \mathrm{Zr}_{1.75} \mathrm{Ta}_{0.25} \mathrm{O}_{12}$ solid electrolytes. Solid State Ionics. 2013; 253 (18): 76-80.

[39] $\mathrm{Xu}, \mathrm{B} \mathrm{Li}, \mathrm{W}$ Duan, $\mathrm{H}$, et al. $\mathrm{Li}_{3} \mathrm{PO}_{4}$-added garnet-type $\mathrm{Li}_{6.5} \mathrm{La}_{3} \mathrm{Zr}_{1.5} \mathrm{Ta}_{0.5} \mathrm{O}_{12}$ for Li-dendrite suppression. Journal of Power Sources. 2017; 354: 68-73.

[40] Janani, N Deviannapoorani, C Dhivya, L, et al. Influence of sintering additives on densification and $\mathrm{Li}^{+}$conductivity of $\mathrm{Al}$ doped $\mathrm{Li}_{7} \mathrm{La}_{3} \mathrm{Zr}_{2} \mathrm{O}_{12}$ lithium garnet. Rsc Advances. 2014; 4 (93): 51228-51238.

[41] Tadanaga, K Takano, R Ichinose, T, et al. Low temperature synthesis of highly ion conductive $\mathrm{Li}_{7} \mathrm{La}_{3} \mathrm{Zr}_{2} \mathrm{O}_{12}-\mathrm{Li}_{3} \mathrm{BO}_{3}$ composites. Electrochemistry Communications. 2013; 33 (8): 51-54.

[42] Li, Y Xu, B Xu, H, et al. Hybrid Polymer/Garnet Electrolyte with a Small Interfacial Resistance for Lithium-Ion Batteries. Angew Chem Int Ed Engl. 2017; 56 (3): 753-756.

[43] Hayashi, ATatsumisago, M. Invited paper: Recent development of bulk-type solid-state rechargeable lithium batteries with sulfide glass-ceramic electrolytes. Electronic Materials Letters. 2012; 8 (2): 199-207. 
[44] Kim, J Eom, M Noh, S, et al. Effect of mixing method on the properties of composite cathodes for all-solid-state lithium batteries using $\mathrm{Li}_{2} \mathrm{~S}-\mathrm{P}_{2} \mathrm{~S}_{5}$ solid electrolytes. Journal of Power Sources. 2013; 244 (4): 476-481.

[45] Kitamura, H. Fabrication of electrode-electrolyte interface in all-solid-state rechageble lithium batteries by using a supercooled liquid state of the glassy electrolytes. J.mater.chem. 2010; 21 (1): 118-124.

[46] Hayashi, A Nishio, Y Kitaura, H, et al. Novel technique to form electrode-electrolyte nanointerface in all-solid-state rechargeable lithium batteries. Electrochemistry Communications. 2008; 10 (12): 1860-1863.

[47] Haruyama, J Sodeyama, K Han, L, et al. Space-Charge Layer Effect at Interface between Oxide Cathode and Sulfide Electrolyte in All-Solid-State Lithium-Ion Battery. Chemistry of Materials. 2014; 26 (14): 4248-4255.

[48] Sakuda, A Hayashi, A Ohtomo, T, et al. All-solid-state lithium secondary batteries using $\mathrm{LiCoO}_{2}$ particles with pulsed laser deposition coatings of $\mathrm{Li}_{2} \mathrm{~S}-\mathrm{P}_{2} \mathrm{~S}_{5}$ solid electrolytes. Journal of Power Sources. 2012; 196 (16): 6735-6741.

[49] Ohta, N Takada, K Zhang, L, et al. Enhancement of the High-Rate Capability of Solid-State Lithium Batteries by Nanoscale Interfacial Modification . Advanced Materials. 2010; 18 (17): 2226-2229.

[50] Nagao, M Hayashi, A Tatsumisago, M, et al. In situ SEM study of a lithium deposition and dissolution mechanism in a bulk-type solid-state cell with a $\mathrm{Li}_{2} \mathrm{~S}-\mathrm{P}_{2} \mathrm{~S}_{5}$ solid electrolyte. Physical Chemistry Chemical Physics. 2013; 15 (42): 18600-18606.

[51] Sakuda, A Hayashi, ATatsumisago, M. Interfacial Observation between $\mathrm{LiCoO}_{2}$ Electrode and $\mathrm{Li}_{2} \mathrm{~S}-\mathrm{P}_{2} \mathrm{~S}_{5}$ Solid Electrolytes of All-Solid-State Lithium Secondary Batteries Using Transmission Electron Microscopy. Chemistry of Materials. 2010; 22 (3): 949-956.

[52] Kim, K H Iriyama, Y Yamamoto, $\mathrm{K}$, et al. Characterization of the interface between $\mathrm{LiCoO}_{2}$ and $\mathrm{Li}_{7} \mathrm{La}_{3} \mathrm{Zr}_{2} \mathrm{O}_{12}$ in an all-solid-state rechargeable lithium battery. Journal of Power Sources. 2011; 196 (2): 764-767.

[53] Kato, $\mathrm{T}$ Hamanaka, $\mathrm{T}$ Yamamoto, $\mathrm{K}$, et al. In-situ $\mathrm{Li}_{7} \mathrm{La}_{3} \mathrm{Zr}_{2} \mathrm{O}_{12} / \mathrm{LiCoO}_{2}$ interface modification for advanced all-solidstate battery. Journal of Power Sources. 2014; 260 (16): 292-298.

[54] Luo, W Gong, Y Zhu, Y, et al. Transition from Superlithiophobicity to Superlithiophilicity of Garnet Solid-State Electrolyte. Journal of the American Chemical Society. 2016; 138 (37): 12258.

[55] Ohta, S Komagata, S Seki, J, et al. All-solid-state lithium ion battery using garnet-type oxide and $\mathrm{Li}_{3} \mathrm{BO}_{3}$ solid electrolytes fabricated by screen-printing. Journal of Power Sources. 2013; 238: 53-56.

[56] Kun (Kelvin) Fu Yunhui Gong Boyang Liu, et al. Toward garnet electrolyte-based Li metal batteries: An ultrathin, highly effective, artificial solid-state electrolyte/metallic Li interface. SCIENCE ADVANCES. 2017; 3: 11.

[57] Murugan, R Thangadurai, VWeppner, W. Fast lithium ion conduction in garnet-type $\mathrm{Li}_{7} \mathrm{La}_{3} \mathrm{Zr}_{2} \mathrm{O}_{12}$. Angew Chem Int Ed Engl. 2007; 46 (41): 7778-7781.

[58] Saccoccio, $\mathrm{M} \mathrm{Yu}, \mathrm{J} \mathrm{Lu}, \mathrm{Z}$, et al. Low temperature pulsed laser deposition of garnet $\mathrm{Li}_{6.4} \mathrm{La}_{3} \mathrm{Zr}_{1.4} \mathrm{Ta}_{0.6} \mathrm{O}_{12}$ films as all solid-state lithium battery electrolytes. Journal of Power Sources. 2017; 365: 43-52.

[59] Jiajia TanTiwari, A. Characterization of $\mathrm{Li}_{7} \mathrm{La}_{3} \mathrm{Zr}_{2} \mathrm{O}_{12}$ Thin Films Prepared by Pulsed Laser Deposition. Mater. Res. Soc. Symp. Proc. 2012; 1471.

[60] Jiajia Tan, A T. Fabrication and Characterization of $\mathrm{Li}_{7} \mathrm{La}_{3} \mathrm{Zr}_{2} \mathrm{O}_{12}$ Thin Films for Lithium Ion Battery. ECS Solid State Letters. 2012; 1 (6): 4.

[61] Rawlence, M Garbayo, I Buecheler, S, et al. On the chemical stability of post-lithiated garnet Al-stabilized $\mathrm{Li}_{7} \mathrm{La}_{3} \mathrm{Zr}_{2} \mathrm{O}_{12}$ solid state electrolyte thin films. Nanoscale. 2016; 8 (31): 14746-14753.

[62] Reinacher, J Berendts, SJanek, J. Preparation and electrical properties of garnet-type $\mathrm{Li}_{6} \mathrm{BaLa}_{2} \mathrm{Ta}_{2} \mathrm{O}_{12}$ lithium solid electrolyte thin films prepared by pulsed laser deposition. Solid State Ionics. 2014; 258: 1-7.

[63] Kim, S Hirayama, M Taminato, S, et al. Epitaxial growth and lithium ion conductivity of lithium-oxide garnet for an all solid-state battery electrolyte. Dalton Trans. 2013; 42 (36): 13112-13117.

[64] Jung Hoon Park Wan-Shick Hong Park, J S, et al. Aluminum Migration during Deposition of $\mathrm{Li}_{7} \mathrm{La}_{3} \mathrm{Zr}_{2} \mathrm{O}_{12}$ Thin Films on Aluminum Oxide Substrates. ECS Transactions. 2013; 53 (36): 4.

[65] Park, J S Cheng, L Zorba, V, et al. Effects of crystallinity and impurities on the electrical conductivity of Li-La-Zr-O thin films. Thin Solid Films. 2015; 576: 55-60.

[66] Park, J H Hong, W-S Park, J S, et al. Aluminum Migration during Deposition of $\mathrm{Li}_{7} \mathrm{La}_{3} \mathrm{Zr}_{2} \mathrm{O}_{12}$ Thin Films on Aluminum Oxide Substrates. In Battery Electrolytes; Alamgir, F.; Jow, R.; Thangadurai, V.; Henderson, W.; Mukerjee, S.; Trulove, P., Eds.; 2013; pp 1-5.

[67] Rawlence, M Garbayo, I Buecheler, S, et al. On the chemical stability of post-lithiated garnet Al-stabilized $\mathrm{Li}_{7} \mathrm{La}_{3} \mathrm{Zr}_{2} \mathrm{O}_{12}$ solid state electrolyte thin films. Nanoscale. 2016; 8 (31): 14746-14753.

[68] Kim, S Hirayama, M Taminato, S, et al. Epitaxial growth and lithium ion conductivity of lithium-oxide garnet for an all solid-state battery electrolyte. Dalton Transactions. 2013; 42 (36): 13112-13117.

[69] Kalita, D J Lee, S H Lee, K S, et al. Ionic conductivity properties of amorphous Li-La-Zr-O solid electrolyte for thin film batteries. Solid State Ionics. 2012; 229: 14-19.

[70] Lobe, S Dellen, C Finsterbusch, M, et al. Radio frequency magnetron sputtering of $\mathrm{Li}_{7} \mathrm{La}_{3} \mathrm{Zr}_{2} \mathrm{O}_{12}$ thin films for solid- 
state batteries. Journal of Power Sources. 2016; 307: 684-689.

[71] Katsui, H Goto, T. Preparation of cubic and tetragonal $\mathrm{Li}_{7} \mathrm{La}_{3} \mathrm{Zr}_{2} \mathrm{O}_{12}$ film by metal organic chemical vapor deposition. Thin Solid Films. 2015; 584: 130-134.

[72] Christoph Loho Ruzica Djenadic Michael Bruns, et al. Garnet-Type $\mathrm{Li}_{7} \mathrm{La}_{3} \mathrm{Zr}_{2} \mathrm{O}_{12}$ Solid Electrolyte Thin Films Grown by $\mathrm{CO}_{2}$-Laser Assisted CVD for All-Solid-State Batteries. Journal of The Electrochemical Society. 2017 ; 164 (1): 9.

[73] Loho, C Djenadic, R Bruns, M, et al. Garnet-Type $\mathrm{Li}_{7} \mathrm{La}_{3} \mathrm{Zr}_{2} \mathrm{O}_{12}$ Solid Electrolyte Thin Films Grown by CO2-Laser Assisted CVD for All-Solid-State Batteries. Journal of the Electrochemical Society. 2017; 164 (1): A6131-A6139.

[74] Katsui, HGoto, T. Preparation of cubic and tetragonal $\mathrm{Li}_{7} \mathrm{La}_{3} \mathrm{Zr}_{2} \mathrm{O}_{12}$ film by metal organic chemical vapor deposition. Thin Solid Films. 2015; 584 : 130-134.

[75] James A. Raiford, Caleb C. Boyd, Axel F. Palmstrom et al. Enhanced Nucleation of Atomic Layer Deposited Contacts Improves Operational Stability of Perovskite Solar Cells in Air. Adv. Energy Mater.2019, 1902353.

[76] Pengfei Yan, Jianming Zheng, Jian Liu et al. Tailoring grain boundary structures and chemistryof Ni-rich layered cathodes for enhanced cycle stability of lithium-ion batteries. Nature Energy. 2018; 3: 600-605.

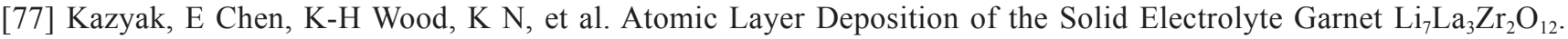
Chemistry of Materials. 2017; 29 (8): 3785-3792.

[78] Hanft, D Exner, J Moos, R. Thick-films of garnet-type lithium ion conductor prepared by the Aerosol Deposition Method: The role of morphology and annealing treatment on the ionic conductivity. Journal of Power Sources. 2017; 361: 61-69.

[79] Cheol-Woo Ahn Jong-Jin Choi Jungho Ryu, et al. Microstructure and Ionic Conductivity in $\mathrm{Li}_{7} \mathrm{La}_{3} \mathrm{Zr}_{2} \mathrm{O}_{12} \mathrm{Film}$ Prepared by Aerosol Deposition Method. Journal of The Electrochemical Society. 2015; 162 (1): 4.

[80] Chen, R-J Huang, M Huang, W-Z, et al. Sol-gel derived Li-La-Zr-O thin films as solid electrolytes for lithium-ion batteries. Journal of Materials Chemistry A. 2014; 2 (33): 13277.

[81] Tadanaga, K Egawa, H Hayashi, A, et al. Preparation of lithium ion conductive Al-doped $\mathrm{Li}_{7} \mathrm{La}_{3} \mathrm{Zr}_{2} \mathrm{O}_{12}$ thin films by a sol-gel process. Journal of Power Sources. 2015; 273: 844-847.

[82] Mina Zarabian Monica Bartolini Pedro Pereira-Almao, et al. X-ray Photoelectron Spectroscopy and AC Impedance Spectroscopy Studies of Li-La-Zr-O Solid Electrolyte Thin Film-LiCoO 2 Cathode Interface for All-Solid-State Li Batteries. Journal of The Electrochemical Society. 2017; 164 (6): 7.

[83] Chen, R-J Huang, M Huang, W-Z, et al. Sol-gel derived Li-La-Zr-O thin films as solid electrolytes for lithium-ion batteries. Journal of Materials Chemistry A. 2014; 2 (33): 13277-13282.

[84] Tadanaga, K Egawa, H Hayashi, A, et al. Preparation of lithium ion conductive Al-doped $\mathrm{Li}_{7} \mathrm{La}_{3} \mathrm{Zr}_{2} \mathrm{O}_{12}$ thin films by a sol-gel process. Journal of Power Sources. 2015; 273 (Supplement C): 844-847.

[85] Zarabian, M Bartolini, M Pereira-Almao, P, et al. X-ray Photoelectron Spectroscopy and AC Impedance Spectroscopy Studies of Li-La-Zr-O Solid Electrolyte Thin Film/LiCoO 2 Cathode Interface for All-Solid-State Li Batteries. Journal of the Electrochemical Society. 2017; 164 (6): A1133-A1139.

[86] Gong, Y Zhang, J Jiang, L, et al. In Situ Atomic-Scale Observation of Electrochemical Delithiation Induced Structure Evolution of $\mathrm{LiCoO}_{2}$ Cathode in a Working All-Solid-State Battery. Journal of the American Chemical Society. 2017; 139 (12): 4274-4277.

[87] Chan, C K Yang, T Mark Weller, J. Nanostructured Garnet-type $\mathrm{Li}_{7} \mathrm{La}_{3} \mathrm{Zr}_{2} \mathrm{O}_{12}$ : Synthesis, Properties, and Opportunities as Electrolytes for Li-ion Batteries. Electrochimica Acta. 2017; 253: 268-280.

[88] Keller, M Appetecchi, G B Kim, G-T, et al. Electrochemical performance of a solvent-free hybrid ceramic-polymer electrolyte based on $\mathrm{Li}_{7} \mathrm{La}_{3} \mathrm{Zr}_{2} \mathrm{O}_{12}$ in P(EO) $)_{15}$ LiTFSI. Journal of Power Sources. 2017; 353: 287-297.

[89] Yang, T Zheng, J Cheng, Q, et al. Composite Polymer Electrolytes with $\mathrm{Li}_{7} \mathrm{La}_{3} \mathrm{Zr}_{2} \mathrm{O}_{12}$ Garnet-Type Nanowires as Ceramic Fillers: Mechanism of Conductivity Enhancement and Role of Doping and Morphology. ACS Appl Mater Interfaces. 2017; 9 (26): 21773-21780.

[90] Fu, K K Gong, Y Dai, J, et al. Flexible, solid-state, ion-conducting membrane with 3D garnet nanofiber networks for lithium batteries. Proc Natl Acad Sci U S A. 2016; 113 (26): 7094-7099.

[91] Zheng, J Tang, MHu, Y Y. Lithium Ion Pathway within $\mathrm{Li}_{7} \mathrm{La}_{3} \mathrm{Zr}_{2} \mathrm{O}_{12}$-Polyethylene Oxide Composite Electrolytes. Angew Chem Int Ed Engl. 2016; 55 (40): 12538-12542.

[92] Zheng, J Dang, H Feng, X, et al. Li-ion transport in a representative ceramic-polymer-plasticizer composite electrolyte: $\mathrm{Li}_{7} \mathrm{La}_{3} \mathrm{Zr}_{2} \mathrm{O}_{12}$-polyethylene oxide-tetraethylene glycol dimethyl ether. Journal of Materials Chemistry A. 2017; 5 (35): 18457-18463.

[93] Frederieke, Langer Sofia, Palagoni, M Ingo, Bardenhagen, et al. Impedance Spectroscopy Analysis of the Lithium Ion Transport through the $\mathrm{Li}_{7} \mathrm{La}_{3} \mathrm{Zr}_{2} \mathrm{O}_{12} / \mathrm{P}(\mathrm{EO})_{20} \mathrm{Li}$ Interface. Journal of The Electrochemical Society. $2017 ; 164$ (12): 6.

[94] Liu, W Lee, S W Lin, D, et al. Enhancing ionic conductivity in composite polymer electrolytes with well-aligned ceramic nanowires. Nature Energy. 2017; 2 (5): 17035.

[95] Zhang, J Zhao, N Zhang, M, et al. Flexible and ion-conducting membrane electrolytes for solid-state lithium batteries: 
Dispersion of garnet nanoparticles in insulating polyethylene oxide. Nano Energy. 2016; 28: 447-454.

[96] Zhang, X Liu, T Zhang, S, et al. Synergistic Coupling between $\mathrm{Li}_{6.75} \mathrm{La}_{3} \mathrm{Zr}_{1.75} \mathrm{Ta}_{0.25} \mathrm{O}_{12}$ and Poly(vinylidene fluoride) Induces High Ionic Conductivity, Mechanical Strength, and Thermal Stability of Solid Composite Electrolytes. $J$ Am Chem Soc. 2017; 139 (39): 13779-13785.

[97] Chen, L Li, Y Li, S-P, et al. PEO/garnet composite electrolytes for solid-state lithium batteries: From "ceramic-inpolymer" to "polymer-in-ceramic". Nano Energy. 2018; 46: 176-184.

[98] Chen, F Yang, D Zha, W, et al. Solid polymer electrolytes incorporating cubic $\mathrm{Li}_{7} \mathrm{La}_{3} \mathrm{Zr}_{2} \mathrm{O}_{12}$ for all-solid-state lithium rechargeable batteries. Electrochimica Acta. 2017; 258: 1106-1114.

[99] Chen, R J Zhang, Y B Liu, T, et al. Addressing the Interface Issues in All-Solid-State Bulk-Type Lithium Ion Battery via an All-Composite Approach. ACS Appl Mater Interfaces. 2017; 9 (11): 9654-9661.

[100] Tao, X Liu, Y Liu, W, et al. Solid-State Lithium-Sulfur Batteries Operated at 37 degrees $\mathrm{C}$ with Composites of Nanostructured $\mathrm{Li}_{7} \mathrm{La}_{3} \mathrm{Zr}_{2} \mathrm{O}_{12} /$ Carbon Foam and Polymer. Nano Lett. 2017; 17: 2967-2972.

[101] Yan, X Li, Z Wen, Z, et al. Li/ $/ \mathrm{Li}_{7} \mathrm{La}_{3} \mathrm{Zr}_{2} \mathrm{O}_{12} / \mathrm{LiFePO}$ All-Solid-State Battery with Ultrathin Nanoscale Solid Electrolyte. The Journal of Physical Chemistry C. 2017; 121 (3): 1431-1435.

[102] Yan, X Li, Z Ying, H, et al. A novel thin solid electrolyte film and its application in all-solid-state battery at room temperature. Ionics. 2018; 24: 1545-1551. 